\title{
Scripta
}

\section{Els exempla de Valeri Màxim a la literatura catalana medieval}

\section{The exempla of Valerius Maximus in medieval Catalan literature}

\author{
Helena Rovira Cerdà \\ helenarovirac@gmail.com
}

I. $S$.

Resum: Diverses obres en llengua catalana dels s. XIV-XV contenen nombrosos exempla procedents, de forma directa o indirecta, dels Dictorum factorumque memorabilium libri novem de Valeri Màxim. En aquest article incloem una taula on es localitzen 233 episodis de l'autor romà en 24 obres escrites en català, tant originals com traduccions. A més, analitzem el procés de transmissió dels episodis inclosos en el Memorial del pecador remut de Felip de Malla, la Doctrina compendiosa atribuïda per uns a Francesc Eiximenis i per altres a Ramon Soler, la Doctrina moral de Nicolau de Pacs, el Llibre del joc dels escacs de Jaume de Cèssulis, el Recull d'exemples d'Arnau de Lieja, i altres obres amb una presència més esporàdica d'episodis dels Dicta com ara l'anònim Curial e Güelfa, La nau de Lleonard de Sors i les Flors de virtut e de costums traduïdes per Francesc de Santcliment.

Paraules clau: Valeri Màxim, exempla, oratòria, intertextualitat, literatura catalana medieval.

\begin{abstract}
Many works written in Catalan during the XIV and XV centuries transmit several exempla from the Dictorum factorumque memorabilium libri novem of Valerius Maximus. In this paper we include a table with the exact location of 233 episodes in 24 Catalan works. Moreover, we examine more deeply the transmission of these episodes in Felip de Malla's Memorial del pecador remut, the Doctrina compendiosa attributed by some to Francesc Eiximenis and by others to Ramon Soler, the Doctrina moral of Nicolau de Pacs, the Llibre del joc dels escacs of Jacobus de Cessolis, the Recull d'exemples of Arnold of Liége, and some other works with less passages related to Valerius Maximus, as the anonymous Curial e Güelfa, La nau of Lleonard de Sors and the Flors de virtut e de costums translated by Francesc de Santcliment.
\end{abstract}

Keywords: Valerius Maximus, exempla, oratory, intertextuality, medieval Catalan literature. 


\section{Introducció}

En aquestes pàgines mostrem els resultats d'una recerca sobre la presència dels episodis narrats als Dictorum factorumque memorabilium libri novem de Valeri Màxim en la literatura escrita en llengua catalana -tant obres originals com traduccions- dels s. XIV-XV, al marge de la traducció catalana d'aquesta obra acabada per Antoni Canals el 1395 o poc abans. La informació que tot seguit incloem es completa amb la continguda en un altre article recentment publicat on analitzàvem els episodis dels Dicta presents al Breviloqui i a la Suma de col tacions de Joan de Gal les, al Regiment de la cosa pública de Francesc Eiximenis, a Lo somni de Bernat Metge i al Tirant lo Blanch de Joanot Martorell. ${ }^{1}$ Ara ens centrarem en el Memorial del pecador remut (1419-1424) de Felip de Malla, la Doctrina compendiosa (ca. 1395) atribuïda a Francesc Eiximenis fins que Curt Wittlin proposà l'autoria de Ramon Soler, la Doctrina moral (1395-1410) de Nicolau de Pacs, les traduccions catalanes del Liber de moribus hominum et de officiis nobilium super ludo scacchorum de Jaume de Cèssulis i de l'Alphabetum narrationum d'Arnau de Lieja, les quals daten respectivament de mitjan s. XIV i mitjan s. XV, i un petit grup d'obres que de manera molt més esporàdica contenen exempla dels Dicta o al ludeixen indirectament a algun passatge de Valeri Màxim.

Per altra banda, incloem una taula amb la localització concreta d'aquests episodis en les obres estudiades -no només en aquest article sinó també en l'anterior, on no oferíem aquesta informació-, acompanyades d'un índex de fonts que identifica l'edició emprada en cada cas. De la ingent quantitat d'anècdotes recollides per l'historiador romà, almenys dues-centes trenta-tres apareixen en una obra que als s. XIV o XV podia llegir-se en llengua catalana. Per facilitar la identificació dels episodis sense allargar excessivament aquest article, incloem després de la taula un breu resum d'aquelles anècdotes reproduïdes per tres o més autors. Per a la resta, el lector pot acudir a alguna de les fonts que, segons la taula, transmeten l'episodi en qüestió.

\section{Obres que contenen exempla de Valeri Màxim}

Com veurem tot seguit, l'ús dels Dicta varia molt entre unes obres i altres, així com la procedència de la informació. Sota Autora (2015), per exemple, podíem veure com el Breniloquium i el Communiloquium de Joan de Gal les, en tant que compendis, eren les obres que incloïen el major nombre d'episodis ja narrats per Valeri Màxim, els quals, al seu torn, havien inspirat els casos paral lels continguts al Regiment de la cosa pública de Francesc Eiximenis. A Lo somni de Bernat Metge, en canvi, la major part dels passatges se centraven en un catàleg de dones il lustres que el notari barceloní havia manllevat no només de l'original llatí de Valeri Màxim sinó també de Petrarca i Boccaccio. Uns

1 Vid. Autora (2015). En realitat, aquest darrer treball fou redactat abans d'Autora (2014: 51-78), on es donava a conèixer una primera visió general sobre la presència de Valeri Màxim a la literatura catalana medieval. L'article que ara iniciem completa i actualitza aquestes aportacions precedents, tot oferint un resum dels exempla més reiterats, una taula més completa i algunes dades addicionals sobre la presència de l'autor romà a les obres catalanes que analitazem a les pàgines següents. 
quants d'aquests episodis apareixien també al Tirant lo Blanch, així com altres que Joanot Martorell havia adaptat a partir de la traducció d'Antoni Canals.

Si ens centrem en els autors que comentarem específicament en aquest article, Felip de Malla, dissetè president de la Generalitat, recorda un passatge dels Dicta (I.7.e3) en un dels parlaments que pronuncià en un certamen poètic celebrat el 1413 a Barcelona, en presència de Ferran I. ${ }^{2}$ Pel que fa a la seva obra més destacada, el Memorial del pecador remut, conté almenys setze episodis provinents dels Dicta, tretze dels quals són enumerats de manera successiva en un mateix passatge, que reproduïm a continuació:

E si d'aquells qui fora los límits terrenals no han stesa lur sperança plau a tu que t faça menció, occorren e són presents denant los ulls de la mia potència aprehensiva Marchus Règulus, qui sforçadament sofferí mort a ell irrogada per los cartaginences, e Oràtius Cocles, qui sol, per la salut romana resistí als toscans e lls lançà en lo flum Tibre, e Cíncius, cavaller romà, qui per salut pòblica dins un cahos se precipità en Roma per tant que, ell morint, fes cessar plagues de ayre pestilent. E Múcius, altre cavaller romà, qui lo seu braç dret exhibí a les flames ardens, per tal com havia errat lo colp contra Porcenna, d'on lo dit rey Porsenna, admirant la pertinàcia de aquest, e tement car cascun és senyor de la vida de l'altre qui menysprea la sua, tractà pau ab la ciutat romana; (...) Ponpeyus no dubtà lo seu dit col locar entre les brasses vives, per dar entendre que per turments del món no revelaria los secrets del senat de Roma. Encara més, la cosa pública dels romans en los dies de la sua opugnació e persecució ha haüds dos hòmens, pare e fill, appellats Decis, voluntàriament lurs persones a mort offerins per la salut comuna, e per ço dix d'aquests dos Valeri Máximo, libro $\mathrm{V}$, que la vida lur obtench a Roma que no fos vençuda, e la lur mort la féu vencedora (...) Què diré de Codrus, rey de Athenes, de Leònides, o Pílades, e Ligurgus, prínceps de la nasció lacedemònica o spartana? D'aquells dos Philenos de la ciutat cartaginesa; de Anaxarcus, philòsof constant qui davant Craton, tiran del regne de Chipre, se gosà la lengua ab les dens tallar e aquella menudament trocejar, e en la faç del tiran scupir, que li manava un sacret descobrir? (Malla 1981-1986: I, 139-141)

En tot aquest fragment, l'única referència explícita a una font és l'al lusió al llibre V de l'obra de Valeri Màxim, tot i que aquesta nota només és vàlida per als dos Decis; de la resta, no en diu res, malgrat que els podem trobar tots ells als Dicta, sobretot en els llibres III i V, tal com es pot comprovar a la taula que incloem més endavant. Per altra banda, al Memorial hi ha almenys quatre referències més als Dicta, les tres primeres a dins d'una altra enumeració de personatges: «axí com Cathó, Lucrècia, Saül e son patge, e Achitofel, e Gaius Màrius, e Gaius Gracus, cavallers romans; d'els parla Valeri, libro VI, cap. viii» (Malla 1981-1986: I, 135; cf. Redondo 2011: 638). Certament els dos Gaius apareixen al sisè llibre dels Dicta, així com la història de Lucrècia, que és mencionada a l’inici d'aquest. Finalment, ja en el capítol quart del Memorial se cita directament en llatí un fragment

2 El passatge de Malla on cita Valeri Màxim diu: «E [el rei Ferran] sab que [l’eloqüència] quaix ret los homens per fama immortals, axi com diu Valeri quod Symonides quendam aeternitati suo carmine consecrauit» (Pujol 1994: 200, on ja s’inclouen entre claudàtors els afegits de la cita; cf. l'edició d’Olivar en Malla 1921: 10).

SCRIPTA, Revista internacional de literatura i cultura medieval i moderna, núm. 5 / juny 2015 / pp. 21 - 51 ISSN: 2340-4841 · doi:10.7203/SCRIPTA.5.6378 
sobre l'amistat: «Nulla tam modesta felicitas est que malignitatis dentes nitare possit» (cf. Valerius Maximus 1854: 370).

Així doncs, d'aquest text podem destacar el fet que els episodis provinents de Valeri Màxim no són extensament reproduïts sinó enumerats de manera ràpida i succinta, fet que afavoreix la sensació que l'autor els coneix de primera mà i els empra amb desimboltura.

La mateixa familiaritat amb el text llatí es percep en l'autor de la Doctrina compendiosa, atribuïda segons alguns testimonis medievals a Francesc Eiximenis, tot i que més recentment Curt Wittlin l'ha assignada a Ramon Soler. ${ }^{3}$ Aquesta obra inclou almenys sis passatges procedents dels Dicta, citats segons l'original llatí tot afegint-ne la corresponent traducció catalana i algunes reflexions relatives al contingut dels episodis en qüestió. En la major part dels casos no se'ns explica cap anècdota concreta, sinó que s'aprofiten sentències que l'autor romà fa a l'inici d'alguns capítols, principalment consideracions personals sobre virtuts i vicis morals: l'ociositat, la impossibilitat d'aconseguir honor sense passar per la prova, i les virtuts de la moderació. A continuació en reproduïm un fragment a tall d'exemple:

Item, Valèrius Màximus, aprés que hac molt parlat de la amor e pietat que deu ésser haüda per cascú vers pare e mare, fills, germans e altres perents e amics, dix tals paraules:

Arctissimis sanguinis uinculis peitas satis fecit; restat nunc ut patria exhibeatur, cuius maiestati etiam illa quae deorum numinibus aequatur auctoritas parentum uires suas subiecit; fraterna quoque caritas anima aequo libenter cedit summa quidem cum ratione. Quia, euersa domo, intemptatus reipublicae status manere potest; urbis ruina penates omnium secum trahat necesse est. Verum quid attinet uerbis ista complecti? Quorum tanta uis est ut aliqui ea salutis suae impendio testati sunt.

Vol dir que «als molts estret ligaments de sanc la pietat hi ha satisfet». Entén-ho a dir per ço que ell dessús havia declarat. «Resta ara», diu ell, «que sia exhibuïda la pietat o retuda a la pàtria, ço és a la cosa pública, a la majestat de la qual, encara, aquella auctoritat de pare e de mare la qual és egualada ab los acostaments o magestat dels déus, sotsmet les sues forces; e la caritat fraternal ab egual coratge e volenterosament li dóna loc, e tot açò ab molt gran raó, car, destrouïda a vegades casa de singular, l'estament de la cosa pública pot romandre e estar, mas ruïna de destrucció de la ciutat força és que ab si se'n port les cases de tots los singulars. ¿E què val», diu ell, «abraçar ab paraules aquestes coses la força de les quals és tanta com alguns han estificat o demostrat per sosteniment de dan de lur pròpria salut o de lur propri bé». Aprés de les quals paraules tantost Valèrius, per prova de aquelles, nomena e recita alcuns valents hòmens qui per la salut e bé de la cosa pública no rebutjaren de sofrir mort e altres dans en lurs persones e béns, voluntàriament e de certa sciència.

E de totes les dites paraules podem traure - dix lo frare- dues coses substancials. La primera és que la amor e caritat envers la cosa pública és possada tan alta que és egualada ab aquella dels déus que’ls

\footnotetext{
3 Han publicat aquest tractat el pare Martí de Barcelona (1929) i Wittlin (Soler 2006). La seva atribució a Eiximenis ja fou descartada per Riera i Sans (1984).
} 
gentils en aquells temps colien. Car Valèrius era gentil e fo ja enans de l'aveniment del Fill de Déu. (Martí de Barcelona 1929: 112-114)

Com hem pogut comprovar, l'autor no només cita, literalment i en llatí, un llarg fragment de Valeri Màxim que tracta sobre l'amor a la pàtria, sinó que en fa un comentari i contextualització tot explicant allò que l'autor romà recontava en els capítols precedents. L'única anècdota de caràcter narratiu que es reprodueix quasi íntegrament pretén recalcar què és la bona amistat: quan en un assumpte tèrbol un amic demana ajuda a Rutili, aquest s'hi nega. Interrogat per l'amic de què li serveix, doncs, la seva amistat, Rutili respon: «què he io obs la tua si per tu he a fer res deshonestament?» (Martí de Barcelona 1929: 62; cf. Dicta VI.4.4). La reproducció, en la majoria de casos literal, de fragments més o menys llargs dels Dicta i el coneixement que demostra de les seqüències d'episodis ens fan considerar la possibilitat que l'autor de la Doctrina compendiosa tingués al davant un còdex amb el text llatí de l'autor romà.

Una altra Doctrina, la del mallorquí Nicolau de Pacs, inclou almenys vuit episodis inspirats en Valeri Màxim. Aquesta obra, escrita poc abans de 1410, és a dir, contemporàniament a la traducció d'Antoni Canals, reprèn diverses fonts, tant antigues com medievals, com bé explica Riquer:

Al costat d'elements procedents del fons cultural medieval, com és per exemple el Tresor de Brunetto Latini, hi trobem adduïts molt sovint autors clàssics (Aristòtil, Sèneca, Ciceró, Juvenal, Valeri Màxim, Cató, Cassiodor, Horaci, Plató, Demòstenes, Boeci, Soló, Ovidi, Lucà, Terenci, etc.). Es fa difícil de precisar quines vegades aquestes referències són de primera mà o depenen d'altres repertoris morals. Però el més interessant de la Doctrina moral és que, de tant en tant, hi apareixen adduïts autors catalans com Arnau de Vilanova, Eiximenis (...), Antoni Canals (del qual manlleva fragments del preàmbul del Scipió e Anibal) i, sobretot, Cerverí. (Riquer 1993 [1964]: II, 307; cf. Martín Pascual 2012)

La dificultat de precisar la font concreta que manllevà Nicolau de Pacs es palesa si considerem que la major part dels vuit episodis que remeten a Valeri Màxim són passatges molt breus i ben coneguts, que es poden trobar també al Communiloquium, a l'Speculum maius de Vicent de Beauvais, al Dotzè d'Eiximenis, al Recull d'exemples d'Arnau de Lieja o al llibre dels escacs de Jaume de Cèssulis. Ara bé, cal destacar que l'únic fragment que per la seva extensió es presta a la comparació amb altres textos presenta unes similituds amb la traducció d'Antoni Canals molt remarcables: 
Diu Valeri que com Camilio regis en lo ofici de la senyoria posats iutges per corregir les costumes dels homens feren una statud e ley per la qual obligaren e feren tributaris aquells qui no volgueren de lur vida pendre muller venint a la lur velleza manantlos que portassen lo dit trahut al erari qui era loch ond metien la moneda del publich e denunciarenlos quels punirien pus agrament sis gosaven en res clamar de la ley o constitucio que tant iustament havien feta e increparenlos per la seguent forma dient:

Natura humana axi com vos ha donada ley de creixer axius ha donada ley de engendrar e si havets vergonya del acte de generatio guardats vostres pares quius engendraren eus nodriren obligantvos quels engenrrassets els nodrissets nets car desiiaven perpetuar lur linatge e per ço havets aconseguit do de fortuna quius ha prestat lonch temps per engendrar semblants de vosaltres mateys e durant aquest temps los vostres dies son passats e perduts e vosaltres romanets de nom de pare e de marit. Anatsvosen donchs e pagats lo tribut a vosaltres aspre e profitos als homens qui apres de vos seran engendrats pus axi havets menyspreada la humana generacio. (Bofarull 1857: 290)
Com Camillo e Postumio regissen loffici de la Censoria, posats jutges per corregir les costumes dels homens, obligaren e feren trahutaris a aquells qui no volgren, de lur vida, pendre muller, viuint axi fins a la lur vellea; manant los que portassen lo dit trahut al errari, qui era lo loch on posauen la moneda del ben publich. E denunciaren los quels punirien pus agrament, sis gosauen clamar en res, de la ley e constitucio que hauien feta tan justament; e increparen los, sots la forma seguent:

Natura humana, axi com vos ha donat ley de nexer, axius ha dat ley de engenrar; e si hauets uergonya del acte de generacio, guardats als vostres pares, quius engenraren eus nodriren, obligant vos quels engenrassets els nodrissets nets, car desijauen perpetuar lur linyatge. E per aço hauets aconseguit do de fortuna, queus ha prestat lonch temps, per engenrar semblant de vosaltres meteys; e durant aquest temps los vostres ayns son passats e perduts, vosaltres romanints priuats de nom de pare e de marit. Anatsvosen, donchs, e pagats lo trahut, a vosaltres aspre, e profitos als homens qui, apres vosaltres, seran engenrats; pus que hauets axi menyspreada la humanal generacio. (Canals 1914: I, 142-143)

Cal tenir en compte que ens basem en edicions publicades i no en la consulta directa dels testimonis manuscrits. Tanmateix, és evident la relació entre ambdós fragments, especialment en la repetició de parelles sinonímiques i en la inclusió d'amplificacions explicatives per a clarificar quina és la tasca del censor i per a definir erari. Així doncs, de la mateixa manera que se sap que l'autor de la Doctrina consultà l'Scipió e Aníbal d'Antoni Canals, podem suposar que també coneixia la seva traducció del Valeri Màxim, la qual cosa situa la redacció de l'esmentada Doctrina el 1395 o poc després.

La identificació de les fonts intermèdies és més senzilla en la següent obra que comentarem, la traducció del llibre dels escacs de Jaume de Cèssulis. La connexió amb l'Speculum maius de Vicent de Beauvais i, dins d'aquest compendi, especialment les parts titulades Speculum historiale i Speculum doctrinale fou estudiada per Mehl (1978), que utilitzà, entre altres mecanismes d'anàlisi, el que ell va anomenar arguments sériels, és a dir, la localització de seqüències d'episodis dispersos als Dicta, però reunits segons un ordre successiu en l'obra d'aquest dominic francès: 
Par ailleurs il connaît directement quelques auteurs anciens. Il les préfère parfois à des sources plus récentes. Mais le plus souvent son choix va aux exempla déjà préparés et classés dans un ordre sans doute plus conforme aux esprits du XIII ${ }^{\mathrm{e}}$ siècle, ordre que lui propose Vincent de Beauvais. (Mehl 1978: 237)

Al Llibre del joc dels escacs hem localitzat cinquanta-dos episodis que remeten a l'autoritat de Valeri Màxim. Segons Mehl (1978: 236), només dotze en deriven directament, tot i que aquest investigador no indica de quins casos es tracta. Com que quinze dels exemples en qüestió són absents als compendis de Vicent de Beauvais i tres d'aquests sí que apareixen al Policraticus - una altra font citada per Mehl-, hem de suposar que els dotze restants són els que ell considera procedents d'algun testimoni llatí dels Dicta.

Ara bé, com a mínim deu d'aquests dotze episodis es troben o bé al Communiloquium o bé al Breniloquium de Joan de Gal les, dues obres que incorporen també passatges sobre els escacs. Precisament per això tant Vidmanovà (Jaume de Cèssulis 1990) com Bataller (2009) apunten diversos casos de possible influència del Breniloquium sobre el Liber de moribus. Aquest darrer estudiós, concretament, constata «la falta de coincidència en els resultats d'aquest treball de Vidmanovà amb el de Mehl (...), el qual en cap moment cita Joan de Gal les com a font directa per als exempla» (Bataller 2009: 181). I la influència de Joan de Gal les sobre Jaume de Cèssulis no només és cronològicament possible, sinó que també es pot constatar a partir dels arguments sériels que Mehl utilitza per mostrar altres connexions. Presentem la següent taula, que remet per una banda als textos llatins de Valeri Màxim i Vicent de Beauvais i, per altra banda, a les traduccions catalanes dels tractats de Joan de Gal les i Jaume de Cèssulis.

\begin{tabular}{|l|l|l|l|l|}
\hline \multicolumn{1}{|c|}{ Dicta } & \multicolumn{1}{|c|}{$\begin{array}{c}\text { Speculum } \\
\text { Maius } \\
\text { (AVB 2004) }\end{array}$} & \multicolumn{1}{|c|}{$\begin{array}{c}\text { Breviloqui } \\
\text { (Joan de Gal les 1930) }\end{array}$} & $\begin{array}{c}\text { Suma de col lacions } \\
\text { (Ramon i Ferrer 1997) }\end{array}$ & \multicolumn{1}{|c|}{$\begin{array}{c}\text { Llibre del joc dels escacs } \\
\text { (Bataller 2009) }\end{array}$} \\
\hline V.1.4 & IV, 98 & p. 111 & p. 114, núm. I.3.5 & p. 482-483 i 484, núm. II.5 \\
\hline V.1.8 & & p. 112 & p. 116, núm. I.3.5 & p. 484, núm. II.5 \\
\hline V.1.9 & p. 111 & p. $115-116$, núm. I.3.5 & p. 483-484, núm. II.5 \\
\hline V.1.10 & p. 111 i 112-113 & p. 116, núm. I.3.5 & p. 483 i 528, núm. II.5 i III.3 \\
\hline
\end{tabular}

Podem concloure, doncs, que Jaume de Cèssulis coneix els Dicta principalment de forma indirecta, ja sigui a través de Vicent de Beauvais, Joan de Salisbury o Joan de Gal les, tot i que normalment remet a la font clàssica. ${ }^{4}$

4 En paraules de Mehl (1978: 239), «Écrire "Refert Valerius" plutôt que "Refert Vincentius Bellovacensis" donnait sans doute plus de poids à l'exemplum». A banda dels treballs ja citats, Cuartero / Mateu (1999) estudien igualment les fonts d'alguns exempla del Liber de moribus de Jaume de Cèssulis. 
La versió catalana de l'Alphabetum narrationum d'Arnau de Lieja, compilat pels volts de l'any 1308 (Arnau de Lieja 2004: I, 43), es coneix com a Recull d'exemples i sol situar-se cronològicament a mitjan s. XV. La traducció introdueix cada exemplum amb una rúbrica que indica l'argument en català, el tema en llatí i el nom de l'autor que serveix de font, que en el nostre cas alterna les variants «Valerianus» $\mathrm{i}$ «Valerius». En tant que compilació d'anècdotes i arguments de diversa procedència, és normal que una de les seves fonts siguin els Dicta, tot i que la seva presència és molt més reduïda del que es podria esperar en una obra d'aquestes característiques: únicament vint-i-set episodis sobre un total de set-cents catorze. ${ }^{5}$ Ben probablement, això es deu al fet que aquest recull dóna preferència als exemples de tradició medieval, circumscrits gairebé sempre a la cultura cristiana, en comparació amb els quals les anècdotes de l'Antiguitat no deixen de ser esporàdiques. De fet, la major part dels vint-i-set casos referents als Dicta il lustren alguna virtut moral perfectament atribuible a la mentalitat cristiana: la caritat envers els pares (ex. 138), la desafecció envers els béns materials (ex. 233 i 234), la lleialtat (ex. 283), la justícia (ex. 351 i 357), l’austeritat (ex. 476) i la castedat (ex. 584 i 685).

\section{Obres amb una presència dels Dicta més esporàdica}

Entre els tractats de vicis i virtuts, l'anònim italià Fiore di virtù fou traduït a la segona meitat del s. $\mathrm{XV}$ per Francesc de Santcliment amb el títol de Flors de virtut e de costums, on s'addueixen nombroses autoritats clàssiques i exemples dels romans antics. Un d'aquests casos, reportat «en les Històries romanes e en Val lèrio Màximo» (Santcliment 1975: 78), recorda l'amistat de Damó i Fínties, anomenats Amon i Físia en aquesta versió, un dels episodis més reproduïts dels Dicta, que descriu com un dels dos protagonistes s'ofereix com a garantia del retorn del seu amic, condemnat a mort. ${ }^{6}$

A banda dels compendis i els tractats doctrinals en català que van circular als s. XIV-XV, altres escriptors van reprendre els Dicta en les seves obres originals. A tall d'exemple, podem recordar alguns casos puntuals que es troben a la narrativa sentimental o cavalleresca i a la lírica amorosa. Si deixem de banda el Tirant lo Blanch, estudiat a Autora (2015), un passatge del Curial e Güelfa que plantejava dificultats de comprensió ha estat degudament interpretat un cop localitzada la seva font en Valeri Màxim (Badia / Torró 2011: 71). Concretament, el llibre III reconta com la Fortuna s'agenolla davant del temple de Venus i demana mercè:

\footnotetext{
5 Entre els vint-i-set episodis que incloem a la taula, n'hi ha alguns que, tot i ser narrats als Dicta, estan referenciats sota una altra font. És el cas d'un exemplum que remet explícitament a «Elinando», és a dir, Helinand de Froidmont, un cronista dels s. XII-XIII, l'obra del qual serveix com a font a Vicent de Beauvais. L'edició i alguns comentaris crítics d'aquesta anècdota que apareix a Dicta VI.3.e3 es poden consultar a Arnau de Lieja (2004: II, 41, núm. 355 «Eximpli con lo ffill de Ciro, rey de Pèrsia, féu escorxar un jutge perquè havie jutjat no justement»).

6 Tal com es pot observar a la taula, aquesta anècdota fou una de les més divulgades de l'obra de Valeri Màxim (IV.7.e1). L'autor romà també se cita com a font en el següent fragment: «Val leri diu: “Tostemps aquell que menaçe se fa tenir més orat que no és”» (Santcliment 1975: 185). Com en el cas de Joan de Montsó, que veurem més endavant, la poca concreció d'aquesta sentència dificulta enormement la localització de la seva font. Segons indica TCM (2012: núm. 0.19.1), existeix una versió catalana inèdita de les Fiore di virtù anterior a la de Francesc de Santcliment.
}

SCRIPTA, Revista internacional de literatura i cultura medieval i moderna, núm. 5 / juny 2015 / pp. 21- 51 ISSN: 2340-4841 · doi:10.7203/SCRIPTA.5.6378 
Mira'm bé, e aqueix teu piadós ull gira'l envers mi, e sia jo mirada per tu ab aquella benignitat e mansuetud que fonc mirat lo violador de la boca, per lo qual fonc respost: «Si als que ens amen matam, ¿què farem a aquells als quals som en oi capital?». (Badia / Torró 2011: 490)

Al darrere d'aquest passatge hi ha l'anècdota narrada als Dicta (V.1.e2) -tot i que, segons Lola Badia i Jaume Torró, filtrada per Dante (Purg. XV, v. 97-104) i Boccaccio (Filocolo, II.53.8; III.34.2; IV.50.5)-, segons la qual l'esposa del tirà Pisistrat demana al seu marit que faci matar un jove per haver besat llur filla en públic, però el tirà respon negativament, amb la sentència reproduïda per l'autor del Curial. Per altra banda, Valeri Màxim és citat explícitament al pròleg del mateix llibre III, al final d'un llistat d'autoritats que inclou Sal lusti, sant Gregori, Ciceró i Pròsper d'Aquitània: «Item Valerius, in titulo "De cupiditate gloriae", "Nulla est tanta bumilitas que dulcedo gloriae non tangatur") (Badia / Torró 2011: 392). Aquest fragment el podem trobar a Dicta VIII.14.5.

En un extens poema al legòric com La nau de Lleonard de Sors, datat pels volts de 1454, trobem almenys dues referències als Dictorum factorumque memorabilium, localitzades per Compagna (1995: 65):

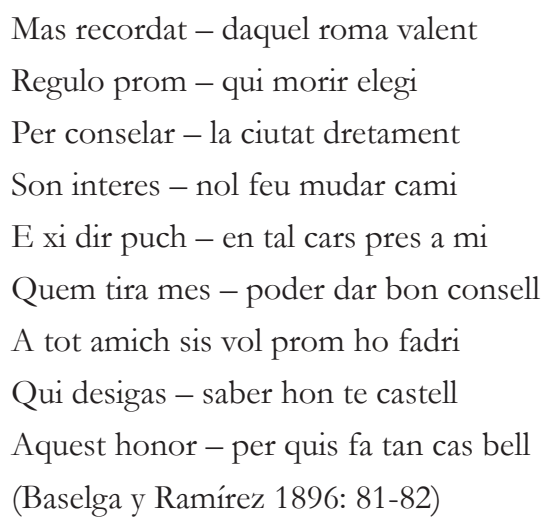

\author{
Prosperitat - atals homens percassa \\ Dos ne coneix - lo valleri quiu narra \\ Sol prosperats - e plens de benanança. \\ Matello quint - de patria romana \\ Es lo primer - aglao se diu laltre \\ Aquest segon - me par nasque en gracia (...) \\ En lo trectat - de benanança u comta \\ Heu sab quiu lig - si bentresil recorde \\ (Baselga y Ramírez 1896: 113)
}

El primer fragment recorda com M. Atili Règul, després de ser capturat pels cartaginesos, és enviat a Roma per negociar el seu intercanvi per un grup de joves presoners cartaginesos. Un cop a la ciutat italiana, el propi Atili parla en contra d'aquest intercanvi afirmant que això no afavorirà als romans. Torna a Cartago, tal i com havia promès, i allà és mort cruelment (Dicta I.1.14). Com es pot veure a la taula, aquest episodi es troba també al Breviloqui de Joan de Gal les, al Regiment d'Eiximenis, al Llibre del joc dels escacs de Jaume de Cèssulis i al Memorial del pecador remut de Felip de Malla. En el segon fragment se cita explícitament «Lo trectat de benanança» de Valeri, fent referència al primer títol del llibre VII dels Dicta, titulat «De felicitate». Aquest títol és molt breu, ja que consta únicament de dos capítols dedicats, precisament, un a Q. Metel i l'altre a Aglau, ciutadà de Psofide, a Grècia.

La traducció del dominic Joan de Montsó als Sermones in Cantica de sant Bernat ha sofert problemes de transmissió i actualment només conserva la carta dedicatòria datada entre 1392 i 1396, endreçada 
a l'infant Martí, futur successor de Joan I a la Corona d'Aragó. ${ }^{7}$ En aquesta epístola trobem el següent passatge: «E en compliment de les vostres armes senyor son aguiles negres en camper blanch. Aquestes foren les armes antiguament del emperador segons que diu Valeri Maximo» (Girona y Llagostera 1919: 467). Ben probablement Joan de Montsó està fent referència a l'àguila, símbol de les legions romanes, tot i que se'ns escapa si el dominic tenia en ment un episodi particular de Valeri Màxim o si, simplement, aprofità aquest nom per recolzar la seva sentència amb una autoritat reconeguda, tot i saber que aquesta connexió podia ser no prou consistent.

Conclourem aquest repertori amb la menció d'alguns documents d'oratòria política, escrits en català, que inclouen referències puntuals i esporàdiques a episodis de Valeri Màxim. Rubió i Lluch (1908-1921: I, 348-349, 413) publicà diverses cartes en què reis catalans mostraven interès per aconseguir un exemplar del nostre autor, i en altres escrits queda ben clar que coneixien prou bé els Dicta com per emprar-los en un discurs. Tal com comenta Rico (1983: 289), Pere el Cerimoniós amonestava l'infant Ferran, en una carta de 1363, tot recordant-li que devia seguir la «doctrina dels antichs» i la valerosa actitud de «Cipió Africhan» enfrontat a «Anibaud». ${ }^{8}$ Sota Autora (2015) mencionàvem també discursos dels reis Joan I i Martí I i del vescomte Pere de Fenollet. Per la seva banda, Marc de Villalba, abat de Montserrat, en una intervenció a les corts tortosines de 1421, feia un parell de referències a Valeri Màxim, tot i que, segons ha demostrat Rico (1983: 284), «lo único que hay es un pasaje de las Familiares (XVIII, I, 30-32) plagiado de forma que las palabras de Petrarca se van repartiendo atribuidas a quien al abad le da la gana»:

Car en los actes comuns e públics devem proceir ab tota celeritat e maturitat, repel lint los extrems, qui són temeritat e peresa. E en los fets perilloses moltes vegades ha més profitat la cuita que llonga del liberació, segons diu Suetoni (in libro De XII Cesaribus); "si llongament hagués tardat Escipió Nasica en proveir, perduda era del tot la glòria de Roma"; segons diu Valeri (libro sexto): "si Juli Cèsar hagués tardat de no proveir tantost, no fóra estat de tot lo món emperador"; segons diu Petrarca De illustribus uiris: "si Claudi Neró hagués tardat de combatre Asdrúbal abans que s'ajustàs ab son frare Haníbal, perdut era del tot l'emperi” (...). (Albert / Gassiot 1928: 141)

Tot i que l'obra de Petrarca que l'abat plagia no identifica el passatge de Valeri Màxim, la menció al llibre VI ha de fer referència a l'episodi narrat a Dicta VI.9.15: quan Cèsar era jove fou capturat per uns pirates, però pagà cinquanta talents i fou alliberat immediatament. El mateix autor romà és al ludit al final del discurs, quan es trauen a col lació «los de Celtibèria, dels quals lo gran Valeri, llur fidelitat innada per tot lo món dignament ha publicada» (Albert / Gassiot 1928: 148). Ben segurament es fa referència a Dicta II.6.11, on es comenta que els celtibers consideren un oprobi sobreviure en una batalla si mor aquell a qui han jurat defensar, i que els alegra més poder morir lluitant per la pàtria que de malaltia.

7 Vid. BITECA (2014: TEXID 1773), TCM (2012: núm. 22.5.1) i Riquer (1993 [1964]: II, 242-243).

8 Vid. Rubió i Balaguer (1936: 345-346). El passatge citat pel rei Pere es troba a Dicta V.6.7.

SCRIPTA, Revista internacional de literatura i cultura medieval i moderna, núm. 5 / juny 2015 / pp. 21- 51 ISSN: 2340-4841 ·doi:10.7203/SCRIPTA.5.6378 


\section{Conclusions}

Qualsevol lector dels s. XIV-XV que conegués el català podia llegir en aquesta llengua episodis provinents dels Dicta de Valeri Màxim, algunes vegades amb un reconeixement explícit de la font i altres vegades com a anècdota al ludida per l'autor sense identificar-ne l'origen. De fet, el punt de partida no sempre era el text llatí de Valeri Màxim o la traducció d'Antoni Canals enllestida el 1395 o poc abans, sinó que podien ser altres obres en llatí o en alguna llengua vulgar, sobretot l'italià. Aquesta tendència es pot palesar a l'exemple comentat del Curial e Güelfa, on de manera bastant velada s'al ludeix l'anècdota de Valeri Màxim (represa per Dante i per Boccaccio) a través d'una breu però inequívoca referència intertextual.

A causa de la seva exemplaritat, algunes de les anècdotes tingueren un gran ressò i foren incorporades no només a les obres escrites sinó que també eren emprades a l’oratòria pública, tant política com sagrada. En aquest darrer camp només podem basar-nos en el que se'ns ha conservat, com ara els exempla aplegats per Arnau de Lieja o els sermons de sant Vicent Ferrer que referim a la taula. Aquests testimonis demostren com els predicadors medievals tenien un gran interès per ornar la seva doctrina amb exemples que eren a l'abast a través de traduccions i compilacions de l'època.

A continuació, incloem la taula en què se situa la localització exacta dels episodis dels Dicta en vàries obres escrites en català medieval. Els passatges de Valeri Màxim apareixen citats segons el sistema «llibre, títol, capítol», a partir de l'edició de Kempf (Valerius Maximus 1854). També donem la referència a la traducció d'Antoni Canals (1914), ja que no sempre coincideix exactament amb la numeració de l'original llatí. Pel que fa a la identificació de les altres obres, tot seguit oferim un listat de les edicions emprades sota la sigla corresponent. 


\section{Fonts emprades a la taula: identificació de les sigles i edicions consultades}

Arnau de Lieja= Arnau de Lieja (2004) Recull d'exemples i miracles ordenat per alfabet, Ysern Lagarda, J. A. (ed.), Barcelona, Barcino, 2 vols. [Traducció de l'Alphabetum narrationum d'Arnau de Lieja]

$B=$ Joan de Gal les (1930) Breviloqui, Norbert d'Ordal (ed.), Barcelona, Barcino.

$C=$ Ramon i Ferrer, L. (1997) Edició crítica i estudi de la "Summa de col lacions" de Joan de Gal les. Tesi doctoral dirigida pel Dr. Albert G. Hauf i Valls i la Dra. Josepa $\mathrm{M}^{a}$ Cortés i Escrivà, València, Universitat de València. [Tesi en microfitxes amb dues numeracions, una per a l'estudi introductori i una altra per a l'edició]

Canals = Canals, A. (1914) Llibre anomenat Valeri Maximo. Dels dits y fets memorables. Traducció catalana del xiv ${ }^{\text {en }}$ segle per Frare Antoni Canals, Miquel i Planas, R. (ed.), Barcelona, L'Avenç, 2 vols.

Canals 1935= Canals, A. (1935) Scipió e Aníbal. De providència. De arra de ànima, Riquer, M. de (ed.), Barcelona, Barcino.

Curial= Badia, L. / Torró, J. (eds.) (2011) Curial e Güelfa, Barcelona, Quaderns Crema.

$D=$ Eiximenis, F. (2005) Dotzè llibre del Crestià I, 1, Renedo, X. (ed.), Martí, S. (coord.), Girona, Universitat de Girona/Diputació de Girona. [A la taula s'exclou la part del Dotzè que transmet el Regiment de la cosa pública, reflectida a la sigla $R$ ]

$D C=$ Martí de Barcelona (ed.) (1929) Doctrina compendiosa, Barcelona, Barcino.

Dicta $=$ Valerius Maximus (1854) Valerii Maximi factorum et dictorum memorabilium libri nouem cum Iulii Paradis et Ianuarii Nepotani epitomis, Kempf, C. (ed.), Stuttgart, Teubner.

Fenollet= Albert, R. / Gassiot, J. (eds.) (1928) Parlaments a les corts catalanes, Barcelona, Barcino. [Discurs pronunciat per Pere de Fenollet a les corts de Barcelona del 15 de gener de 1409]

Ferrer 1927= Ferrer, V. (sant) (1927) Quaresma de sant Vicent Ferrer predicada a València l'any 1413, Sanchis Sivera, J. (ed.), Barcelona, Institució Patxot. [Sermó de Quaresma de sant Vicent Ferrer]

Ferrer 1985= Perarnau i Espelt, J. (1985) "La compilació de sermons de sant Vicent Ferrer de Barcelona, Biblioteca de Catalunya, ms. 477", Arxiu de Textos Catalans Antics, 4, pp. 213-402. [Sermó de Pentecosta de sant Vicent Ferrer]

Flors = Santcliment, F. de (1975) Flors de virtut, Cornagliotti, A. (ed.), Barcelona, Barcino. [Traducció catalana de l'anònim Fiore di virtū]

Jaume de Cèssulis= Bataller, A. (2009) Les traduccions catalanes del "Liber de moribus hominum et de officiis nobilum super ludo scachorum" de Jacobus de Cessulis. Tesi doctoral dirigida pel Dr. Albert Hauf i Valls, València, 2001, Universitat de València. Departament de Filologia Catalana. URL: <http:// www.tesisenred.net/handle/10803/9811>.

Joan I= Rubió i Lluch, J. (1908-1921) Documents per a la història de la cultura catalana mig-eval, Barcelona, Institut d'Estudis Catalans, 2 vols. [Carta del rei Joan I als prohoms de la ciutat de Barcelona datada a 18 de setembre de 1392] 
L= Eiximenis, F. (1981) Lo libre de les dones, Naccarato, F. (ed.), Coromines, J. (dir.), Wittlin, C. / Comas, A. (revs.), Wittlin, C. (intr. i apèndix), Bover i Font, A. (glossari), Barcelona, Curial, 2 vols.

Lo somni= Metge, B. (2006) Lo somni, Cingolani, S. M. (ed.), Barcelona, Barcino.

Malla 1921= Malla, F. de (1921) Parlaments al Consistori de la Gaia Ciència, Olivar, M. (ed.), Barcelona, Imp. de la Casa de Caritat. [Discurs pronunciat per Felip de Malla en un certamen poètic celebrat a Barcelona el 1413]

Malla 1981-1986= Malla, F. de (1981-1986) Memorial del pecador remut. Manuscrit de Barcelona, Balasch, M. (ed.), Barcelona, Barcino, 3 vols.

Marc de Villalba = Albert, R. / Gassiot, J. (eds.) (1928) Parlaments a les corts catalanes, Barcelona, Barcino. [Discurs pronunciat per Marc de Villalba, abat de Montserrat, a les corts tortosines de 1421]

Martí I= Albert, R. / Gassiot, J. (eds.) (1928) Parlaments a les corts catalanes, Barcelona, Barcino. [Discursos del rei Martí I]

Nau= Baselga y Ramírez, M. (1896) El Cancionero catalán de la Universidad de Zaragoza, Saragossa, Cecilio Gasca. [La nau de Lleonard de Sors]

Pacs= Bofarull i Mascaró, P. de (ed.) (1857) Colección de documentos inéditos del Archivo general de la Corona de Aragón. Volumen XIII. Documentos literarios en antigua lengua catalana (siglos XIV y XV), Barcelona, Imprenta del Archivo. [Doctrina moral de Nicolau de Pacs a les pp. 186-303].

R= Eiximenis, F. (1927) Regiment de la cosa pública, Daniel de Molins de Rei (ed.), Barcelona, Barcino.

T= Eiximenis, F. (1929-1932) Terc del Crestià, Martí de Barcelona / Norbert d'Ordal (eds.), Barcelona, Barcino.

Tirant lo Blanch= Martorell, J. / (Martí Joan de Galba) (2005) Tirant lo Blanch, Hauf, A. (ed.), València, Tirant lo Blanch. 
Helena Rovira Cerdà. Els exempla de Valeri Màxim a la literatura catalana medieval

Taula d'episodis dels Dicta en obres en llengua catalana dels s. XIV-XV

\begin{tabular}{|c|c|c|c|c|c|c|c|c|}
\hline Dicta & Canals & Joan de Gal les & $\begin{array}{c}\text { Jaume } \\
\text { de } \\
\text { Cèssulis }\end{array}$ & $\begin{array}{c}\text { Arnau } \\
\text { de } \\
\text { Lieja }\end{array}$ & $\begin{array}{c}\text { Francesc } \\
\text { Eiximenis }\end{array}$ & $\begin{array}{c}\text { Lo somni de } \\
\text { Bernat } \\
\text { Metge }\end{array}$ & $\begin{array}{l}\text { Tirant lo } \\
\text { Blanch }\end{array}$ & $\begin{array}{l}\text { Altres } \\
\text { obres i } \\
\text { autors }\end{array}$ \\
\hline I.1.14 & I.1.17 & B, p. 33-34 & $\begin{array}{l}\text { p. } \begin{array}{l}\quad 475- \\
47\end{array}, \\
\text { n ú m } \\
\text { II.5 }\end{array}$ & & $\begin{array}{l}\text { R, p. 93-94, } \\
\text { núm. 14 }\end{array}$ & & & $\begin{array}{l}\text { Malla 1981- } \\
\text { 1986: II, p. } \\
139 \\
\text { Nau, p. } 81- \\
82 \\
\text { Joan I, vol. } \\
\text { I, p. } 376\end{array}$ \\
\hline I.1.15 & I.1.18 & B, p. 53 & & & & & & \\
\hline I.5.2 & I.3.3 & $\begin{array}{l}\text { C, p. 52, núm. } \\
\text { I.1.11 }\end{array}$ & & & $\begin{array}{ll}\text { R, p. } & 119- \\
120, & \text { núm. } \\
20 & \end{array}$ & & & \\
\hline I.6.13 & I.4.14 & & & & & $\begin{array}{l}\text { p. } 152 \text {, núm. } \\
\text { I.v.31 }\end{array}$ & & \\
\hline I.6.e1 & I.4.15/16 & $\begin{array}{l}\text { C, p. 242, núm. } \\
\text { I.6.3 }\end{array}$ & & & $\begin{array}{l}\text { D, II.2, p. } 97 \text {, } \\
\text { núm. } 717\end{array}$ & & & \\
\hline I.7.e3 & I.5.11 & & & & & & & $\begin{array}{l}\text { Malla 1921: } \\
10\end{array}$ \\
\hline I.8.1 & I.6.1-3 & & & & & $\begin{array}{l}\text { p. 152, núm. } \\
\text { I.v.31 }\end{array}$ & & \\
\hline II.1.3 & II.1.2 & $\begin{array}{l}\text { C, p. } 387-388, \\
\text { núm. II.4.6 }\end{array}$ & & & $\begin{array}{l}\text { D, II.1, p. } \\
\text { 394, núm. } \\
845 \\
\text { L, I, p. } 150 \text {, } \\
\text { núm. } 99\end{array}$ & & & \\
\hline II.1.4 & II.1.3 & $\begin{array}{l}\text { C, p. 387, núm. } \\
\text { II.4.6 }\end{array}$ & & & $\begin{array}{l}D, \text { II.2, p. } 55 \text {, } \\
\text { núm. } 787\end{array}$ & & & \\
\hline II.1.5 & II.1.4 & $\begin{array}{l}\text { B, p. } 92 \\
\text { C, p. 106, 278, } \\
378 \text { i } 439 \text {, núm. } \\
\text { I.3.3, I.8.7, II.4.2 } \\
\text { i III.1.2 }\end{array}$ & $\begin{array}{l}\text { p. } \quad 508, \\
\text { n ú m . } \\
\text { III.1 }\end{array}$ & & $\begin{array}{l}\text { T, III, p. } 285 \text {, } \\
\text { núm. } 350\end{array}$ & & & \\
\hline II.1.6 & II.1.4 & $\begin{array}{l}\text { C, p. 388, núm. } \\
\text { II.4.6 }\end{array}$ & & & $\begin{array}{l}\text { D, II.1, p. } \\
393 \text {, núm. } \\
844\end{array}$ & & & \\
\hline II.1.8 & II.1.6 & $\begin{array}{l}\text { C, p. 605, núm. } \\
\text { IV.3.12 }\end{array}$ & & & & & & \\
\hline II.1.10 & II.1.8 & & & & & & & $\begin{array}{l}\text { Martí I, p. } \\
59-60\end{array}$ \\
\hline II.2.1 & II.1.9-10 & $\begin{array}{l}\text { C, p. } 55-56 \text { i } 251 \text {, } \\
\text { núm. I.1.11 i } \\
\text { I.6.9 }\end{array}$ & & & $\begin{array}{l}D, \text { II.2, p. } 97, \\
\text { núm. } 717\end{array}$ & & & \\
\hline II.2.5 & II.1.14 & & & & & & $\begin{array}{l}\text { p. 1233, núm. } \\
349\end{array}$ & \\
\hline II.6.10 & II.1.37 & & & & & $\begin{array}{l}\text { p. 152, núm. } \\
\text { I.v.31 }\end{array}$ & & \\
\hline II.6.11 & II.1.38 & & & & & & & $\begin{array}{l}\text { Marc de } \\
\text { Villalba, p. } \\
148\end{array}$ \\
\hline II.6.14 & II.1.41 & $\begin{array}{l}\text { C, p. 384, núm. } \\
\text { II.4.4 }\end{array}$ & & & & & & \\
\hline II.6.17 & II.1.44 & $\begin{array}{l}\text { C, p. 131, núm. } \\
\text { I.3.8 }\end{array}$ & & & & & & \\
\hline
\end{tabular}

SCRIPTA, Revista internacional de literatura i cultura medieval i moderna, núm. 5 / juny 2015 / pp. 21- 51 
Helena Rovira Cerdà. Els exempla de Valeri Màxim a la literatura catalana medieval

\begin{tabular}{|c|c|c|c|c|c|c|c|}
\hline II.7.1 & II.2.1 & $\begin{array}{l}\text { B, p. } 93 \\
\text { C, p. } 295-296 \text { i } 156 \text {, } \\
\text { núm. I.9.5, I.3.16 }\end{array}$ & $\begin{array}{l}\text { p. } \quad 545 \text {, } \\
\text { n ú m . } \\
\text { III.5 }\end{array}$ & $\begin{array}{l}\text { D, II.1, p. } \\
459 \text {, núm. } \\
656\end{array}$ & & $\begin{array}{l}\text { p. } \quad \text { 608-609, } \\
\text { núm. } 143\end{array}$ & \\
\hline II. 7.2 & II.2.2 & $\begin{array}{l}\text { C, p. 296, núm. } \\
\text { I.9.5 }\end{array}$ & & & & & \\
\hline II.7.4 & II.2.4 & $\begin{array}{l}\text { B, p. } 59 \\
\text { C, p. 302, núm. } \\
\text { I.9.6 }\end{array}$ & & $\begin{array}{l}\text { D, II.1, p. } \\
\text { 433, núm. } \\
862\end{array}$ & & & \\
\hline II.7.6 & II.2.6-7 & $\begin{array}{l}\text { C, p. } 53 \text { i 298, núm. } \\
\text { I.1.11 i I.9.5 }\end{array}$ & & $\begin{array}{l}\text { R, p. } 117 \text { i } \\
120-121, \\
\text { núm. } 19 \text { i } \\
20 \\
D \text {, II.1, p. } \\
433 \text {, núm. } \\
862\end{array}$ & & & Pacs, p. 296 \\
\hline II.7.8 & II.2.9 & $\begin{array}{l}C \text {, p. 298, núm. } \\
\text { I.9.5 }\end{array}$ & & & & & \\
\hline II.7.10 & II.2.11 & $\begin{array}{l}C \text {, p. } 705 \text {, núm. } \\
\text { VI.4.3 }\end{array}$ & & & & & \\
\hline II.7.11 & II.2.12 & $\begin{array}{l}\text { C, p. 298, núm. } \\
\text { I.9.5 }\end{array}$ & & & & & \\
\hline II.7.12 & II.2.13 & $\begin{array}{l}\text { C, p. 298, núm. } \\
\text { I.9.5 }\end{array}$ & & & & & \\
\hline II.7.13 & II.2.13 & $\begin{array}{l}\text { C, p. 298, núm. } \\
\text { I.9.5 }\end{array}$ & & & & & \\
\hline II.7.14 & II.2.13 & $\begin{array}{l}\text { C, p. 298, núm. } \\
\text { I.9.5 }\end{array}$ & & & & & \\
\hline II.7.15 & II.2.14-17 & $\begin{array}{l}\text { B, p. } 57 \\
\text { C, p. 298, núm. } \\
\text { I.9.5 }\end{array}$ & & & & & \\
\hline II.7.e2 & II.2.19 & $\begin{array}{l}\text { C, p. 299, núm. } \\
\text { I.9.5 }\end{array}$ & & & & & \\
\hline III.8.0 & II.3.1 & $\begin{array}{l}\text { C, p. 299, núm. } \\
\text { I.9.5 }\end{array}$ & & & & & \\
\hline II.9.1 & II.4.1 & & & & & & Pacs, p. 290 \\
\hline II.10.0 & II.5.1 & & & & & & $D C$, p. 103 \\
\hline II.10.2 & II.5.2 & & & & & & $\begin{array}{l}\text { Fenollet, p. } \\
79\end{array}$ \\
\hline III.2.1 & III.2.1 & & & & & & $\begin{array}{l}\text { Malla 1981- } \\
\text { 1986: II, p. } \\
\text { 139-140 }\end{array}$ \\
\hline III.2.2 & III. 2.2 & & & & $\begin{array}{l}\text { p. } 240-241 \text {, } \\
\text { n ú m } \\
\text { IV.iv. } 24\end{array}$ & & \\
\hline III.2.3 & III.2.3 & $\begin{array}{l}\text { C, p. 302, núm. } \\
\text { I.9.6 }\end{array}$ & & & & & \\
\hline III.2.e3 & III.2.29 & $\begin{array}{l}\text { B, p. } 132-133 \\
\text { C, p. 295, núm. } \\
\text { I.9.4 }\end{array}$ & & & & & $\begin{array}{l}\text { Malla 1981- } \\
\text { 1986: II, p. } \\
141\end{array}$ \\
\hline IIII.3.1 & III.3.1 & & & & & & $\begin{array}{l}\text { Malla 1981- } \\
\text { 1986: II, p. } \\
\text { 140 }\end{array}$ \\
\hline III.3.2 & III.3.2-3 & B, p. 131 & & & & & $\begin{array}{l}\text { Malla 1981- } \\
\text { 1986: II, p. } \\
140\end{array}$ \\
\hline III.3.e1 & III.3.4-5 & B, p. 53 i 131 & & & & & \\
\hline III.3.e2 & III.3.6 & B, p. 131-132 & & & & & \\
\hline
\end{tabular}

SCRIPTA, Revista internacional de literatura i cultura medieval i moderna, núm. 5 / juny 2015 / pp. 21- 51

ISSN: 2340-4841 $\cdot$ doi:10.7203/SCRIPTA.5.6378 
Helena Rovira Cerdà. Els exempla de Valeri Màxim a la literatura catalana medieval

\begin{tabular}{|c|c|c|c|c|c|c|c|c|}
\hline III.3.e3 & III.3.7 & $B$, p. 132 & & & & & & \\
\hline III.3.e4 & III.3.8 & B, p. 132 & $\begin{array}{c}\text { p. } \quad 493- \\
494 \\
\text { n ú m . } \\
\text { II.5 }\end{array}$ & & & & & $\begin{array}{l}\text { Malla 1981- } \\
\text { 1986: II, p. } \\
141\end{array}$ \\
\hline III.3.e7 & III.3.11 & $\begin{array}{l}\text { C, p. 344, núm. } \\
\text { II.1.5 }\end{array}$ & & & & & & \\
\hline III.4.1 & III.4.1 & $\begin{array}{l}C \text {, p. } 473 \text {, núm. } \\
\text { III.3.3 }\end{array}$ & & & & & & \\
\hline III.4.e1 & III.4.7 & $\begin{array}{l}\text { C, p. } \quad 473-474 \text {, } \\
\text { núm. III.3.3 }\end{array}$ & & & & & & \\
\hline III.4.e2 & III. 4.7 & $\begin{array}{l}\text { C, p. 474, núm. } \\
\text { III.3.3 }\end{array}$ & & & & & & \\
\hline III.5.0 & III.5.1 & $\begin{array}{l}\text { C, p. 471-472, } \\
\text { núm. III.3.1 }\end{array}$ & & & & & & \\
\hline III.7.1 & III.7.1-4 & B, p. 98 & $\begin{array}{l}\text { p. } \quad 495- \\
496 \\
\text { n ú m. } \\
\text { II.5 }\end{array}$ & & & & $\begin{array}{l}\text { p. 606, núm. } \\
143\end{array}$ & \\
\hline III.7 e8 & III.7.21 & B, p. 125-126 & & & & & & \\
\hline III.8.2 & III.8.2 & & & & & $\begin{array}{l}\text { p. 245, núm. } \\
\text { IV.iv.34 }\end{array}$ & & \\
\hline III.8.7 & III.8.7 & $\begin{array}{l}\text { C, p. 339, núm. } \\
\text { II.1.4 }\end{array}$ & & & & & & \\
\hline III.8.8 & III. 8.8 & $\begin{array}{l}\text { C, p. 339, núm. } \\
\text { II.1.4 }\end{array}$ & & & & & & \\
\hline III.8.e2 & III.8.10 & $\begin{array}{l}C \text {, p. 250, núm. } \\
\text { I.6.8 }\end{array}$ & & & $\begin{array}{c}D, \quad \text { II.2, p. } \\
113 \text {, núm. } \\
724\end{array}$ & & & \\
\hline III.8.e6 & III.8.14 & B, p. 124 & & & & & $\begin{array}{l}\text { p. 606, núm. } \\
143\end{array}$ & \\
\hline IV.1.1 & IV.1.1 & & $\begin{array}{l}\text { p. } \quad 486, \\
\text { n ú m. } \\
\text { II.5 }\end{array}$ & & & & & \\
\hline IV.1.5 & IV.1.5 & & $\begin{array}{l}\text { p. } \quad 487, \\
\text { n ú m. } \\
\text { II. } 5\end{array}$ & $\begin{array}{l}\text { II, p. } \\
188, \\
\text { nú m. } \\
568\end{array}$ & & & & \\
\hline IV.1.6 & IV.1.6 & $\begin{array}{l}\text { C, p. 581, núm. } \\
\text { IV.3.3 }\end{array}$ & & & & & & \\
\hline IV.1.e1 & IV.1.18 & B, p. 139 & $\begin{array}{l}\text { p. } \quad 494, \\
\text { n ú m . } \\
\text { II. } 5\end{array}$ & $\begin{array}{l}\text { II, p. } \\
\text { 38-39, } \\
\text { nú m. } \\
351\end{array}$ & & & & \\
\hline IV.1.e2 & $\begin{array}{l}\text { IV.1.19- } \\
20\end{array}$ & B, p. $124-125$ i 139 & $\begin{array}{l}\text { p. } \quad 494- \\
455 \\
\text { n ú } \mathrm{m} . \\
\text { II. } 5\end{array}$ & $\begin{array}{l}\text { II, p. } \\
\text { 38-39, } \\
\text { nú m. } \\
351\end{array}$ & & & & \\
\hline IV.1.e7 & IV.1.25 & & & $\begin{array}{l}\text { II, p. } \\
214, \\
\text { nú m. } \\
605\end{array}$ & & & & \\
\hline IV.1.e8 & IV.1.26 & $\begin{array}{l}\text { C, p. 121, núm. } \\
\text { I.3.6 }\end{array}$ & & & & & & $\begin{array}{l}D C \text {, p. 126- } \\
127\end{array}$ \\
\hline IV.1.e9 & IV.1.27 & $C$, p. 83, núm. I.2.2 & & & & & & $D C$, p. 127 \\
\hline IV.2.1 & IV.2.1 & C, p. 39, núm. I.1.5 & & & $\begin{array}{c}\text { R, p. } 65 \text { i 85, } \\
\text { núm. } 7 \text { i } 12\end{array}$ & & & \\
\hline
\end{tabular}

SCRIPTA, Revista internacional de literatura i cultura medieval i moderna, núm. 5 / juny 2015 / pp. 21- 51 
Helena Rovira Cerdà. Els exempla de Valeri Màxim a la literatura catalana medieval

\begin{tabular}{|c|c|c|c|c|c|c|c|c|}
\hline IV.3.1 & IV.3.1 & $\begin{array}{l}\text { B, p. } 94-95 \\
\text { C, p. 106-107, } \\
\text { núm. I.3.3 }\end{array}$ & 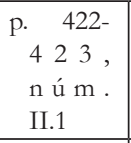 & & $\begin{array}{l}\text { R, p. } 113 \text {, } \\
\text { núm. } 19\end{array}$ & & & \\
\hline IV.3.3 & IV.3.3-4 & & & & $\begin{array}{l}\text { L, I, p. 152, } \\
\text { núm. } 100\end{array}$ & & & \\
\hline IV.3.5 & IV.3.6-7 & B, p. $98-99$ & 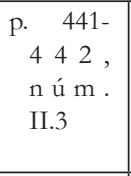 & $\begin{array}{lll}\text { II, } & \text { p. } \\
1 & 2 & 8 \\
1 & 2 & 9 \\
\text { n ú m. } & \\
476\end{array}$ & & & $\begin{array}{l}\text { p. 604, núm. } \\
143\end{array}$ & \\
\hline IV.3.6 & IV.3.8-9 & $\begin{array}{l}\text { B, p. } 38,99 \text { i } 145 \\
\text { C, p. } 684 \text {, núm. } \\
\text { VI. } 2.5\end{array}$ & $\begin{array}{l}\text { p. } \quad 443- \\
4 \quad 4 \quad 4, \\
\text { n ú m. } \\
\text { II.3 }\end{array}$ & & $\begin{array}{l}\text { R, p. } 115 \text {, } \\
\text { núm. } 19\end{array}$ & & & Pacs, p. 191 \\
\hline IV.3.7 & IV.3.10 & $B$, p. 100 & & & & & & \\
\hline IV.3.11 & IV.3.14 & $\begin{array}{l}C \text {, p. 195, núm. } \\
\text { I.4.2 }\end{array}$ & & & & & & \\
\hline IV.3.12 & IV.3.15 & $\begin{array}{l}\text { C, p. 193, núm. } \\
\text { I.4.2 }\end{array}$ & & & & & & \\
\hline IV.3.13 & IV.3.16 & $\begin{array}{l}\text { C, p. 193, núm. } \\
\text { I.4.2 }\end{array}$ & & & & & & \\
\hline IV.3.e1 & IV.3.19 & $\begin{array}{l}C \text {, p. 446, núm. } \\
\text { III.1.3 }\end{array}$ & & & & & & \\
\hline IV.3.e3 & $\begin{array}{l}\text { IV.3.21- } \\
22\end{array}$ & $\begin{array}{l}\text { B, p. } 95-96 \\
\text { C, p. } 695 \text {, núm. } \\
\text { VI. } 3.2\end{array}$ & 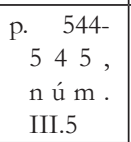 & & & & & \\
\hline IV.3.e4 & $\begin{array}{l}\text { IV.3.23- } \\
24\end{array}$ & $\begin{array}{l}\text { B, p. } 105 \text { i } 122-123 \\
\text { C, p. } 685 \text {, núm. } \\
\text { VI. } 2.5\end{array}$ & & & & & & \\
\hline IV.4.1 & IV.4.1-2 & $\begin{array}{l}\text { B, p. } 36 \\
\text { C, p. 194, núm. } \\
\text { I.4.2 }\end{array}$ & & & $\begin{array}{l}\text { R, p. } 115 \text {, } \\
\text { núm. } 19\end{array}$ & & & \\
\hline IV.4.2 & IV.4.3 & $\begin{array}{l}\text { C, p. 194, núm. } \\
\text { I.4.2 }\end{array}$ & & & & & & \\
\hline IV.4.4 & IV.4.4 & $\begin{array}{l}\text { C, p. 293, núm. } \\
\text { I.9.4 }\end{array}$ & & & & & & \\
\hline IV.4.5 & IV.4.5 & $\begin{array}{l}\text { C, p. } 84-85 \text {, núm. } \\
\text { I.2.3 }\end{array}$ & & & & & & \\
\hline IV.4.6 & $\begin{array}{l}\text { IV.4.6 } \\
\end{array}$ & $B$, p. 37 & & & & & & \\
\hline IV.4.7 & IV.4.7 & B, p. 37 & & & & & & \\
\hline IV.5.e1 & IV.5.7 & $\begin{array}{l}\text { B, p. 93-94 } \\
\text { C, p. 476, núm. } \\
\text { III.3.4 }\end{array}$ & $\begin{array}{l}\text { p. } \quad 526- \\
5 \quad 2 \quad 7, \\
\text { n ú m. } \\
\text { III.3 }\end{array}$ & $\begin{array}{l}\text { II, p. } \\
1998- \\
1199 \\
\text { núm. } \\
584\end{array}$ & & & & \\
\hline IV.6.0 & IV.6.1-2 & & & & $\begin{array}{l}L, \text { I, p. } 130 \text {, } \\
\text { núm. } 84\end{array}$ & & & \\
\hline IV.6.1 & IV.6.1-2 & $\begin{array}{l}\text { C, p. 381, núm. } \\
\text { II.4.3 }\end{array}$ & & & & & & \\
\hline IV.6.2 & IV.6.3 & $\begin{array}{l}\text { C, p. 381, núm. } \\
\text { II.4.3 }\end{array}$ & & & & & & \\
\hline IV.6.3 & IV.6.4 & $\begin{array}{l}\text { C, p. 381, núm. } \\
\text { II.4.3 }\end{array}$ & & & & & & \\
\hline IV.6.4 & IV.6.5 & $\begin{array}{l}\text { C, p. 381, núm. } \\
\text { II.4.3 }\end{array}$ & & & & $\begin{array}{l}\text { p. 236, núm. } \\
\text { IV.iv.13 }\end{array}$ & $\begin{array}{l}\text { p. 1124, núm. } \\
309\end{array}$ & \\
\hline
\end{tabular}

SCRIPTA, Revista internacional de literatura i cultura medieval i moderna, núm. 5 / juny 2015 / pp. 21- 51 
Helena Rovira Cerdà. Els exempla de Valeri Màxim a la literatura catalana medieval

\begin{tabular}{|c|c|c|c|c|c|c|c|c|}
\hline IV.6.5 & IV.6.6 & $\begin{array}{l}\text { C, p. 382, núm. } \\
\text { II.4.3 }\end{array}$ & & & & $\begin{array}{l}\text { p. 236, núm. } \\
\text { IV.iv.12 }\end{array}$ & $\begin{array}{l}\text { p. 1124, núm. } \\
309\end{array}$ & \\
\hline IV.6.e1 & IV.6.7 & & & & & $\begin{array}{l}\text { p. } 236-237, \\
\text { n ú m } \\
\text { IV.iv.14 }\end{array}$ & $\begin{array}{l}\text { p. 1124, núm. } \\
309\end{array}$ & \\
\hline IV.6.e2 & IV.6.8 & $\begin{array}{l}\text { C, p. 382, núm. } \\
\text { II.4.3 }\end{array}$ & & & & $\begin{array}{l}\text { p. 235-236, } \\
\text { n ú m . } \\
\text { IV.iv.11 }\end{array}$ & $\begin{array}{l}\text { p. 1124, núm. } \\
309\end{array}$ & \\
\hline IV.6.e3 & IV.6.9 & $\begin{array}{c}\text { C, p. 383-384, } \\
\text { núm. II.4.4 }\end{array}$ & & & & $\begin{array}{l}\text { p. } 237-238, \\
\mathrm{n} \quad \text { ú } \mathrm{m} . \\
\text { IV.iv.18 }\end{array}$ & & \\
\hline IV.7.0 & IV.7.1-2 & $\begin{array}{l}\text { C, p. 417, núm. } \\
\text { II.7.2 }\end{array}$ & & & & & & \\
\hline IV.7.4 & IV.7.5-6 & & & & $\begin{array}{l}\text { D, II.1, p. } 294 \\
\text { i 300-301, } \\
\text { núm. } 804 \mathrm{i} \\
807\end{array}$ & & & \\
\hline IV.7.e1 & IV.7.10 & $\begin{array}{l}\text { B, p. 50-51 } \\
\text { C, p. 417, núm. } \\
\text { II.7.2 }\end{array}$ & $\begin{array}{l}\text { p. } \begin{array}{l}458- \\
460 \\
\text { n ú m }\end{array} \\
\text { II.4 }\end{array}$ & 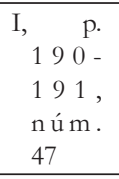 & $\begin{array}{l}\text { D, II.1, p. } \\
294 \text {, núm. } \\
804\end{array}$ & & & $\begin{array}{l}\text { Flors, p. } 78 \\
\text { Pacs, p. } 232\end{array}$ \\
\hline IV.7.e2 & IV.7.11 & & & & $\begin{array}{l}\text { D, II.1, p. } \\
\text { 307, núm. } \\
810\end{array}$ & & & $\begin{array}{l}\text { Malla 1981- } \\
\text { 1986: IV, } \\
\text { 198 }\end{array}$ \\
\hline IV.8.1 & IV.8.1 & & 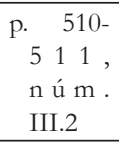 & & & $\begin{array}{l}\text { p. } 244 \text {, núm. } \\
\text { IV.iv.33 }\end{array}$ & & \\
\hline IV.8.2 & IV.8.2 & & & & & $\begin{array}{l}\text { p. 244, núm. } \\
\text { IV.iv.33 }\end{array}$ & & \\
\hline IV.8.e2 & IV.8.8 & $\begin{array}{l}\text { C, p. 135, núm. } \\
\text { I.3.10 }\end{array}$ & & & $\begin{array}{l}\text { D, II.1, p. } \\
\text { 397, núm. } \\
633\end{array}$ & $\begin{array}{l}\text { p. } 244 \text {, núm. } \\
\text { IV.iv.33 }\end{array}$ & & \\
\hline V.1.1 & V.1.1-6 & $\begin{array}{l}\text { B, p. 113-114 } \\
C, \quad \text { p. } \quad 130-131 \text {, } \\
\text { núm. I.3.8 }\end{array}$ & & & $\begin{array}{l}D \text {, II.1, p. } \\
443 \text {, núm. } \\
649\end{array}$ & & & \\
\hline V.1.3 & V.1.8 & $\begin{array}{l}\text { C, p. 601, núm. } \\
\text { IV.3.10 }\end{array}$ & & & & & & \\
\hline V.1.4 & V.1.9 & $\begin{array}{l}\text { B, p. } 111 \\
\text { C, p. } 114 \text {, núm. } \\
\text { I.3.5 }\end{array}$ & $\begin{array}{l}\text { p. } 482- \\
483 \quad \text { i } \\
484 \\
\text { n ú m. } \\
\text { II.5 }\end{array}$ & & & & & \\
\hline $\begin{array}{ll}\text { V.1.8 } \\
\end{array}$ & V.1.13 & $\begin{array}{l}\text { B, p. } 112 \\
\text { C, p. 116, núm. } \\
\text { I.3.5 }\end{array}$ & $\begin{array}{l}\text { p. } \quad 484, \\
\text { n ú m . } \\
\text { II. } 5\end{array}$ & & $\begin{array}{l}D, \quad \text { II.1, p. } \\
301-302, \\
\text { núm. } 598\end{array}$ & & & \\
\hline V.1.9 & V.1.14 & $\begin{array}{l}\text { B, p. } 111 \\
C, \quad \text { p. 115-116, } \\
\text { núm. I.3.5 }\end{array}$ & $\begin{array}{l}\text { p. } 83-84 \text {, } \\
\text { n ú m . } \\
\text { II. } 5\end{array}$ & & $\begin{array}{l}\text { D, II.1, p. } \\
\text { 301, núm. } \\
598\end{array}$ & & & \\
\hline V.1.10 & V.1.15-16 & $\begin{array}{l}\text { B, p. } 111 \text { i 112-3 } \\
\text { C, p. 116, núm. } \\
\text { I.3.5 }\end{array}$ & $\begin{array}{l}\text { p. } 483 \text {, } \\
528, \\
\text { n ú m . } \\
\text { II.5 i } \\
\text { III.3 }\end{array}$ & & $\begin{array}{l}\text { D, II.1, p. } \\
302-303, \\
\text { núm. } 598\end{array}$ & & & \\
\hline
\end{tabular}

SCRIPTA, Revista internacional de literatura i cultura medieval i moderna, núm. 5 / juny 2015 / pp. 21- 51 
Helena Rovira Cerdà. Els exempla de Valeri Màxim a la literatura catalana medieval

\begin{tabular}{|c|c|c|c|c|c|c|c|c|}
\hline V.1.e1 & V.1.18-19 & $\begin{array}{l}\text { B, p. } 115 \\
\text { C, p. 132, núm. } \\
\text { I.3.9 }\end{array}$ & $\begin{array}{l}\text { p. } \quad 485- \\
486, \\
\text { n ú m . } \\
\text { II.5 }\end{array}$ & & $\begin{array}{l}\text { D, II.1, p. } \\
386-387, \\
\text { núm. } 628\end{array}$ & & & \\
\hline V.1.e2 & V.1.20-21 & & $\begin{array}{l}\text { p. } \quad 414 \\
\text { i } \quad 415, \\
\text { n ú m . } \\
\text { II.1 }\end{array}$ & & & & & $\begin{array}{l}\text { Curial, p. } \\
\text { 490, núm. } \\
\text { III.27.6 }\end{array}$ \\
\hline V.1.e3 & V.1.22-23 & B, p. 137 & $\begin{array}{l}\text { p. } \quad 415- \\
416, \\
\text { n ú m . } \\
\text { II.1 }\end{array}$ & & & & & \\
\hline V.1.e6 & V.1.25 & $\begin{array}{l}\text { C, p. 431, núm. } \\
\text { II.9.2 }\end{array}$ & & & & & & \\
\hline V.3.e2 & V.3.13 & $\begin{array}{l}\text { B, p. } 27 \\
\text { C, p. 118, núm. } \\
\text { I.3.6 }\end{array}$ & $\begin{array}{l}\text { p. } \quad 469- \\
470 \\
\text { n ú m . } \\
\text { II.4 }\end{array}$ & & & & & $\begin{array}{l}\text { Malla 1981- } \\
\text { 1986: II, p. } \\
141\end{array}$ \\
\hline V.3.e3 & V.3.14-20 & C, p. 33, núm. I.1.3 & & & & & & Pacs, p. 264 \\
\hline V.4.1 & V.4.1 & $\begin{array}{l}\text { C, p. 358, núm. } \\
\text { II.2.2 }\end{array}$ & & & & & & \\
\hline V.4.7 & V.4.7 & $\begin{array}{l}\text { C, p. 356-357, } \\
\text { núm. II.2.2 }\end{array}$ & $\begin{array}{l}\text { p. } \quad 480- \\
482, \\
\text { n ú m . } \\
\text { II.5 }\end{array}$ & $\begin{array}{l}\text { I, p. } \\
259, \\
\text { nú m. } \\
138\end{array}$ & & $\begin{array}{l}\text { p. 238-239, } \\
\text { n ú m . } \\
\text { IV.iv.19 }\end{array}$ & $\begin{array}{l}\text { p. 1124, núm. } \\
309\end{array}$ & $\begin{array}{l}\text { Ferrer 1927: } \\
\text { 149-150 }\end{array}$ \\
\hline V.4.e1 & V.4.8 & $\begin{array}{l}\text { C, p. 357, núm. } \\
\text { II.2.2 }\end{array}$ & & & & $\begin{array}{l}\text { p. 238-239, } \\
\text { n ú m . } \\
\text { IV.iv.19 }\end{array}$ & & \\
\hline V.4.e5 & V.4.12 & $\begin{array}{l}\text { C, p. } 357-358, \\
\text { núm. II.2.2 }\end{array}$ & & & & & & \\
\hline V.4.e6 & V.4.13 & $\begin{array}{l}\text { C, p. 357, núm. } \\
\text { II.2.2 }\end{array}$ & & & $\begin{array}{l}D \text { II.2, p. } \\
271-272 \text {, } \\
\text { núm. } 794\end{array}$ & & & \\
\hline V.5.2 & V.5.2 & $\begin{array}{l}\text { C, p. 364, núm. } \\
\text { II.3.1 }\end{array}$ & & & & & & \\
\hline V.5.3 & V.5.3 & $\begin{array}{l}\text { C, p. 364, núm. } \\
\text { II.3.1 }\end{array}$ & & & & & & \\
\hline V.5.4 & V.5.4 & $\begin{array}{l}\text { C, p. 364-365, } \\
\text { núm. II.3.1 }\end{array}$ & & & & & & \\
\hline V.6.0 & V.6.1 & $\begin{array}{l}\text { C, p. 52, núm. } \\
\text { I.1.11 }\end{array}$ & & & & & & $\begin{array}{l}\text { DC, p. 112- } \\
114\end{array}$ \\
\hline V.6.2 & V.6.2 & $\begin{array}{l}C, \text { p. 53, núm. } \\
\text { I.1.11 }\end{array}$ & & & $\begin{array}{l}\text { R, p. } 120 \text {, } \\
\text { núm. } 20\end{array}$ & & & $\begin{array}{l}\text { Malla 1981- } \\
\text { 1986: II, p. } \\
140\end{array}$ \\
\hline V.6.3 & V.6.3 & C, p. 83, núm. I.2.2 & & & $\begin{array}{l}\text { R, p. 116, } \\
\text { núm. } 19\end{array}$ & & & \\
\hline V.6.4 & V.6.4 & $\begin{array}{l}\text { C, p. 52, núm. } \\
\text { I.1.11 }\end{array}$ & & & $\begin{array}{l}\text { R, p. } 120 \text {, } \\
\text { núm. } 20\end{array}$ & & & \\
\hline V.6.5 & V.6.5 & & & & & & & $\begin{array}{l}\text { Malla 1981- } \\
\text { 1986: II, p. } \\
140\end{array}$ \\
\hline V.6.6 & V.6.5 & & & & & & & $\begin{array}{l}\text { Malla 1981- } \\
\text { 1986: II, p. } \\
140\end{array}$ \\
\hline V.6.e1 & V.6.8 & $\begin{array}{l}\text { B, p. 34-35 } \\
\text { C, p. 53, núm. } \\
\text { I.1.11 }\end{array}$ & $\begin{array}{l}\text { p. } \quad 465- \\
466, \\
\text { n ú m . } \\
\text { II.4 }\end{array}$ & & $\begin{array}{l}\text { R, p. } 114 \text {, } \\
\text { núm. } 19\end{array}$ & & & $\begin{array}{l}\text { Malla 1981- } \\
\text { 1986: II, p. } \\
140\end{array}$ \\
\hline
\end{tabular}

SCRIPTA, Revista internacional de literatura i cultura medieval i moderna, núm. 5 / juny 2015 / pp. 21- 51 
Helena Rovira Cerdà. Els exempla de Valeri Màxim a la literatura catalana medieval

\begin{tabular}{|c|c|c|c|c|c|c|c|c|}
\hline V.6.e4 & V.6.11 & & & & & & & $\begin{array}{l}\text { Malla 1981- } \\
\text { 1986: II, p. } \\
141\end{array}$ \\
\hline V.6.e5 & V.6.12 & $\begin{array}{l}C \text {, p. 52, núm. } \\
\text { I.1.11 }\end{array}$ & & & & & & \\
\hline V.7.e1 & V.7.4 & $\begin{array}{l}\text { C, p. 353-354, } \\
\text { núm. II.2.1 }\end{array}$ & & & & & & \\
\hline V.8.1 & V.8.1 & $\begin{array}{l}\text { B, p. } 40 \\
\text { C, p. 53, 352, núm. } \\
\text { I.1.11, II.2.1 }\end{array}$ & & & $\begin{array}{l}\text { R, p. 76, } 117 \text {, } \\
\text { núm. } 10 \text { i } \\
19 \\
D \text {, II.1, p. } \\
284 \text {, núm. } \\
592 \\
T, \text { II, p. 36, } \\
\text { núm. } 124\end{array}$ & & & \\
\hline V.8.2 & V.8.2 & $\begin{array}{l}\text { C, p. 352, núm. } \\
\text { II.2.1 }\end{array}$ & & & & & & \\
\hline V.8.3 & V.8.3 & $\begin{array}{l}\text { B, p. } 41 \\
\text { C, p. 352, núm. } \\
\text { II.2.1 }\end{array}$ & & & & & & \\
\hline V.8.5 & V.8.5 & $\begin{array}{l}\text { C, p. 352, núm. } \\
\text { II.2.1 }\end{array}$ & & & & & & \\
\hline V.9.4 & V.9.4 & $\begin{array}{l}\text { C, p. 353, núm. } \\
\text { II.2.1 }\end{array}$ & & & & & & \\
\hline V.10.e2 & V.10.5 & $\begin{array}{l}\text { B, p. } 148 \\
\text { C, p. 56, núm. } \\
\text { I.1.11 }\end{array}$ & & $\begin{array}{l}\text { II, p. } \\
1118, \\
\text { nú m. } \\
461\end{array}$ & $\begin{array}{l}\text { R, p. } 122, \\
\text { núm. } 20\end{array}$ & & $\begin{array}{l}\text { p. 960, núm. } \\
254\end{array}$ & \\
\hline V.10.e3 & V.10.6 & B, p. 148 & & $\begin{array}{l}\text { II, p. } \\
1118, \\
\text { n ú m. } \\
461\end{array}$ & & & $\begin{array}{l}\text { p. 960, núm. } \\
254\end{array}$ & \\
\hline VI.1.1 & VI.1.1 & $\begin{array}{l}\text { C, p. 442, núm. } \\
\text { III.1.3 }\end{array}$ & $\begin{array}{l}\text { p. } \quad 430- \\
434, \\
\text { n ú m . } \\
\text { II.2 }\end{array}$ & & & $\begin{array}{l}\text { p. } 239-240, \\
\text { n ú m } \\
\text { IV.iv.22 }\end{array}$ & & $\begin{array}{l}\text { Malla 1981- } \\
\text { 1986: II, p. } \\
\text { 135 }\end{array}$ \\
\hline VI.1.2 & VI.1.2 & $\begin{array}{l}\text { C, p. } 442 \text {, núm. } \\
\text { III.1.3 }\end{array}$ & & $\begin{array}{l}\text { II, p. } \\
268 \text {, } \\
\text { nú m. } \\
685\end{array}$ & & & & $\begin{array}{l}\text { Pacs, p. 198- } \\
199\end{array}$ \\
\hline VI.1.3 & VI.1.3 & $\begin{array}{l}\text { C, p. 443, núm. } \\
\text { III.1.3 }\end{array}$ & & & & & & \\
\hline VI.1.4 & VI.1.4 & $\begin{array}{l}\text { C, p. 446, núm. } \\
\text { III.1.3 }\end{array}$ & & & & & & \\
\hline VI.1.e1 & VI.1.13 & $\begin{array}{l}\text { C, p. 442, núm. } \\
\text { III.1.3 }\end{array}$ & & & & $\begin{array}{l}\text { p. 240, núm. } \\
\text { IV.iv. } 23\end{array}$ & & \\
\hline VI.1.e3 & VI.1.15 & $\begin{array}{l}\text { C, p. 388, núm. } \\
\text { II.4.6 }\end{array}$ & & & & & & \\
\hline VI.2.1 & VI.2.1 & B, p. 119-120 & & & & & & \\
\hline VI.2.8 & VI.2.7 & B, p. $120-121$ & & & & & & \\
\hline VI.2.10 & VI.2.9 & C, p. 42, núm. I.1.7 & & & $\begin{array}{l}\text { R, p. } \\
106 \text {, núm. } \\
17\end{array}$ & & & \\
\hline VI.2.12 & VI.2.11 & $\begin{array}{l}C \text {, p. } 461 \text {, núm. } \\
\text { IIII.2.5 }\end{array}$ & & & & & & \\
\hline VI.2.e1 & VI.2.12 & $\begin{array}{l}\text { B, p. } 121 \\
\text { C, p. 106, núm. } \\
\text { I.3.3 }\end{array}$ & & & & & & \\
\hline
\end{tabular}

SCRIPTA, Revista internacional de literatura i cultura medieval i moderna, núm. 5 / juny 2015 / pp. 21- 51

ISSN: 2340-4841 $\cdot$ doi:10.7203/SCRIPTA.5.6378 
Helena Rovira Cerdà. Els exempla de Valeri Màxim a la literatura catalana medieval

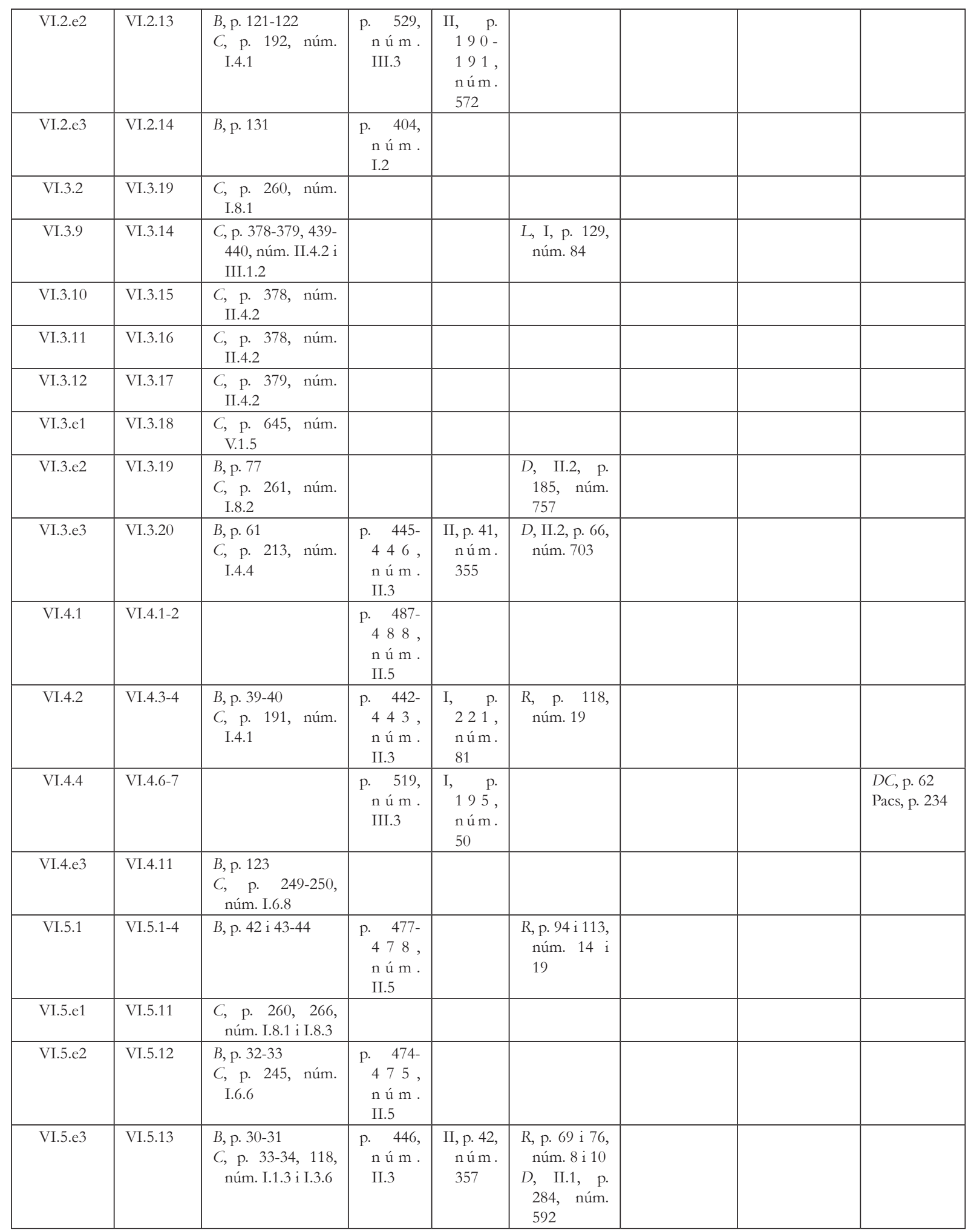

SCRIPTA, Revista internacional de literatura i cultura medieval i moderna, núm. 5 / juny 2015 / pp. 21- 51 
Helena Rovira Cerdà. Els exempla de Valeri Màxim a la literatura catalana medieval

\begin{tabular}{|c|c|c|c|c|c|c|c|}
\hline VI.5.e4 & VI.5.14 & $\begin{array}{l}\text { B, p. } 31 \\
C \text {, p. 118, núm. } \\
\text { I.3.6 }\end{array}$ & $\begin{array}{l}\text { p. } \quad 447, \\
\text { n ú m . } \\
\text { II.3 }\end{array}$ & & & & \\
\hline VI.7.1 & VI.7.1 & $\begin{array}{l}\text { C, p. 383, núm. } \\
\text { II.4.4 }\end{array}$ & & & $\begin{array}{l}\text { p. } 237 \text {, núm. } \\
\text { IV.iv.15 }\end{array}$ & $\begin{array}{l}\text { p. 1124, núm. } \\
309\end{array}$ & \\
\hline VI.7.2 & VI.7.2 & $\begin{array}{l}\text { C, p. 383, núm. } \\
\text { II.4.4 }\end{array}$ & & & $\begin{array}{l}\text { p. } 237 \text {, núm. } \\
\text { IV.iv.16 }\end{array}$ & & \\
\hline VI.7.3 & VI.7.3 & $\begin{array}{l}\text { C, p. 383, núm. } \\
\text { III.4.4 }\end{array}$ & & & $\begin{array}{l}\text { p. } 237 \text {, núm. } \\
\text { IV.iv.17 }\end{array}$ & & \\
\hline VI.8.1 & VI.8.1 & & 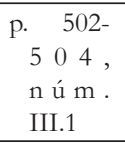 & & & & \\
\hline VI.8.2 & VI.8.2 & & & & & & $\begin{array}{l}\text { Malla 1981- } \\
\text { 1986: II, p. } \\
135\end{array}$ \\
\hline VI.8.3 & VI.8.3 & & & & & & $\begin{array}{l}\text { Malla 1981- } \\
\text { 1986: II, p. } \\
\text { 135 }\end{array}$ \\
\hline VI.8.6 & VI.8.6 & & $\begin{array}{l}\text { p. } \quad 504, \\
\text { n ú m. } \\
\text { III.1 }\end{array}$ & 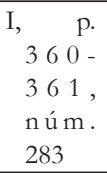 & & & \\
\hline VI.8.7 & VI.8.7 & $\begin{array}{l}\text { C, p. 340, núm. } \\
\text { II.1.4 }\end{array}$ & & & & & \\
\hline VI.9.2 & VI.9.2 & & & & & & $\begin{array}{l}\text { Canals 1935: } \\
34\end{array}$ \\
\hline VI.9.3 & VI.9.3 & $\begin{array}{l}\text { C, p. 569, núm. } \\
\text { IV.2.6 }\end{array}$ & & & & & \\
\hline VI.9.12 & VI.9.12 & $\begin{array}{l}\text { C, p. 525, núm. } \\
\text { III.7.1 }\end{array}$ & & & & & \\
\hline VI.9.13 & VI.9.13 & $\begin{array}{l}\text { C, p. 525, núm. } \\
\text { III.7.1 }\end{array}$ & & & & & \\
\hline VI.9.14 & VI.9.14 & $\begin{array}{l}\text { C, p. 525, núm. } \\
\text { III.7.1 }\end{array}$ & & & & & \\
\hline VI.9.15 & VI.9.15 & & & & & & $\begin{array}{l}\text { Marc de } \\
\text { Villalba, p. } \\
141\end{array}$ \\
\hline VI.9.e1 & VI.9.16 & C, p. 16, núm. I.1.1 & & 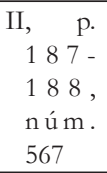 & & & \\
\hline VI.9.e5 & VI.9.20 & $\begin{array}{l}\text { C, p. 524, núm. } \\
\text { III.7.1 }\end{array}$ & & & & & \\
\hline VI.9.e7 & VI.9.22 & 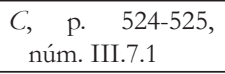 & & & $\begin{array}{l}\text { p. 204, núm. } \\
\text { III.v. } 25\end{array}$ & & \\
\hline VII.1.1 & VII.1.1 & & & & & & Nau, p. 113 \\
\hline VII.1.2 & VII.1.1 & $\begin{array}{l}\text { C, p. 533, núm. } \\
\text { III.7.2 }\end{array}$ & $\begin{array}{l}\text { p. } \quad 606- \\
607, \\
\text { n ú m } \\
\text { IV.7 }\end{array}$ & & & & Nau, p. 113 \\
\hline VII.2.e1 & $\begin{array}{l}\text { VII.2.10- } \\
13\end{array}$ & $\begin{array}{l}\text { B, p. 145-146 } \\
\text { C, p. 373, núm. } \\
\text { II.4.1 }\end{array}$ & $\begin{array}{l}\text { p. } \quad 405, \\
\text { n ú m . } \\
\text { I. } 2\end{array}$ & $\begin{array}{l}\text { II, p. 90, } \\
\text { nú m. } \\
419\end{array}$ & $\begin{array}{l}\text { p. 203, núm. } \\
\text { III.v. } 25\end{array}$ & & \\
\hline VII.2.e2 & $\begin{array}{l}\text { VII.2.14- } \\
16\end{array}$ & $\begin{array}{l}C, \text { p. 527, núm. } \\
\text { III.7.1 }\end{array}$ & & & & & \\
\hline
\end{tabular}

SCRIPTA, Revista internacional de literatura i cultura medieval i moderna, núm. 5 / juny 2015 / pp. 21- 51

ISSN: 2340-4841 $\cdot$ doi:10.7203/SCRIPTA.5.6378 
Helena Rovira Cerdà. Els exempla de Valeri Màxim a la literatura catalana medieval

\begin{tabular}{|c|c|c|c|c|c|c|c|}
\hline $\begin{array}{l}\text { VII.2.e3 } \\
\end{array}$ & VII.2.17 & B, p. 148 & & $\begin{array}{l}\text { I, } \quad \text { p. } \\
324, \\
\text { núm. } \\
234 .\end{array}$ & & & \\
\hline VII.2.e4 & VII.2.18 & $\begin{array}{l}\text { B, p. } 64 \\
\text { C, p. 126, núm. } \\
\text { I.3.7 }\end{array}$ & & & & & \\
\hline VII.2.e5 & VII.2.19 & $\begin{array}{l}\text { B, p. } 75 \\
C \text {, p. } 82-83 \text {, núm. } \\
\text { I.2.22 }\end{array}$ & $\begin{array}{l}\text { p. } \quad 488, \\
\text { nú m. } \\
\text { II.5 }\end{array}$ & & & & \\
\hline VII.2.e6 & VIII.2.20 & & & $\begin{array}{l}\text { II, p. } \\
233, \\
\text { nú m. } \\
633\end{array}$ & & & \\
\hline VII.2.e9 & VII. 2.23 & $\begin{array}{l}\text { B, p. } 71 \\
C, \quad \text { p. 372-373, } \\
\text { núm. II.4.1 }\end{array}$ & & & & & Pacs, p. 196 \\
\hline VII.2.e10 & VII.2.24 & $\begin{array}{l}\text { C, p. 157, núm. } \\
\text { I.3.17 }\end{array}$ & & & & & \\
\hline VII.2.e11 & $\begin{array}{l}\text { VII.2.25- } \\
26 \\
\end{array}$ & B, p. 122 & & & & $\begin{array}{l}\text { p. } 205 \text {, núm. } \\
\text { III.vi.28 }\end{array}$ & \\
\hline VII.2.e12 & \begin{tabular}{|l|l|l} 
VII.2.27 \\
\end{tabular} & $\begin{array}{l}\text { B, p. } 109 \\
\text { C, p. 527, núm. } \\
\text { III.7.1 }\end{array}$ & & & & & \\
\hline VII.2.e14 & VII. 2.29 & $\begin{array}{l}\text { B, p. 32 } \\
C \text {, p. 33, núm. I.1.3 }\end{array}$ & $\begin{array}{l}\text { p. } \quad 447, \\
\text { n ú m. } \\
\text { II.3 }\end{array}$ & & & & \\
\hline VII.2.e15 & VII.2.30 & C, p. 34, núm. I.1.3 & & & & & \\
\hline VII.3.e4 & VII.3.15 & & $\begin{array}{l}\text { p. } \quad 417- \\
4418, \\
\text { n ú m. } \\
\text { II.1 } \\
\end{array}$ & & & & \\
\hline VII.3.e5 & VII.3.16 & $\begin{array}{l}\text { C, p. } 200, \text { núm. } \\
\text { I. } 4.3\end{array}$ & & $\begin{array}{l}\text { I, } \quad \text { p. } \\
244, \\
\text { núm. } \\
118\end{array}$ & $\begin{array}{l}D \text {, II.2, p. } 45 \text {, } \\
\text { núm. } 694\end{array}$ & & \\
\hline VII.4.5 & VII.4.5 & $\begin{array}{l}C \text {, p. } 251 \text {, núm. } \\
\text { I.6.9 }\end{array}$ & & & & & \\
\hline VII.4.7 & & & & & & & $\begin{array}{l}\text { Canals 1935: } \\
32\end{array}$ \\
\hline VII.5.2 & VII.5.2 & $\begin{array}{l}\text { C, p. 459, núm. } \\
\text { III.2.3 }\end{array}$ & & & & & \\
\hline $\begin{array}{l}\text { VII.6.1 } \\
\end{array}$ & VII.6.1-5 & & & & & & $\begin{array}{l}\text { Martí I, p. } \\
78\end{array}$ \\
\hline VIIII.1.1 & VIIII.1.1 & $\begin{array}{l}\text { C, p. 204, núm. } \\
\text { I.4.4 }\end{array}$ & & & $\begin{array}{l}D \text { D, II.2, p. 56, } \\
\text { núm. } 699\end{array}$ & & \\
\hline VIIII.1.2 & VIII.1.2 & $\begin{array}{l}\text { C, p. 205, núm. } \\
\text { I.4.4 }\end{array}$ & & & $\begin{array}{l}D \text {, II.2, p. 56, } \\
\text { núm. } 699\end{array}$ & & \\
\hline VIII.1.6 & VIIII.1.6 & $\begin{array}{l}C, \quad \text { p. } \quad 204-205 \text {, } \\
\text { núm. I.4.4 }\end{array}$ & & & & & \\
\hline VIII.1.7 & VIIII.1.7 & $\begin{array}{l}\text { C, p. 205, núm. } \\
\text { I.4.4 }\end{array}$ & & & & & \\
\hline VIII.1.e2 & VIII.1.15 & $\begin{array}{c}C, \text { p. 202, } 205, \\
\text { núm. I.4.3 i I.4.4 }\end{array}$ & & & $\begin{array}{l}D \text {, II.2, p. 56, } \\
\text { núm. } 699\end{array}$ & & \\
\hline VIII.7.e5 & VIII.7.13 & $\begin{array}{l}\text { B, p. } 69 \\
\text { C, p. } 653 \text {, núm. } \\
\text { V.1.7 } \\
\end{array}$ & $\begin{array}{l}\text { p. } \quad 449, \\
\text { n ú m. } \\
\text { II.3 }\end{array}$ & & & & \\
\hline
\end{tabular}

SCRIPTA, Revista internacional de literatura i cultura medieval i moderna, núm. 5 / juny 2015 / pp. 21- 51

ISSN: 2340-4841 $\cdot$ doi:10.7203/SCRIPTA.5.6378 
Helena Rovira Cerdà. Els exempla de Valeri Màxim a la literatura catalana medieval

\begin{tabular}{|c|c|c|c|c|c|c|c|c|}
\hline $\begin{array}{l}\text { VIII.7.e6 } \\
\end{array}$ & $\begin{array}{l}\text { VIII.7.14 } \\
\end{array}$ & & & 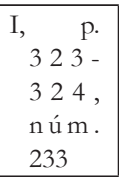 & $\begin{array}{l}\text { D, I.1, p. 408, } \\
\text { núm. 190 }\end{array}$ & & & \\
\hline $\begin{array}{l}\text { VIII.7.e7 } \\
\end{array}$ & VIII.7.15 & $B$, p. 70 & & & & & & \\
\hline VIIII.7.e14 & VIII.7.21 & B, p. 69-70 & & 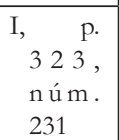 & & & & \\
\hline VIII.7.7e15 & VIII.7.22 & $\begin{array}{l}\text { C, p. 158, núm. } \\
\text { I.3.17 }\end{array}$ & & & & & & \\
\hline $\begin{array}{l}\text { VIII.7.e16 } \\
\end{array}$ & VIII.7.23 & $\begin{array}{l}\text { C, p. 158, núm. } \\
\text { I.3.17 }\end{array}$ & & & & & & \\
\hline VIII.8.0 & $\begin{array}{l}\text { VIII.8.1 } \\
\end{array}$ & & & & & & & $D C$, р. 49 \\
\hline VIIII.13.e2 & VIII.14.8 & $\begin{array}{l}\text { C, p. } 465 \text {, núm. } \\
\text { IIII.2.6 }\end{array}$ & & & & & & \\
\hline $\begin{array}{l}\text { VIII.14.5 } \\
\end{array}$ & VIII.15.5 & & & & & & & $\begin{array}{l}\text { Curial, p. } \\
\text { 392, núm. } \\
\text { III.1.3 }\end{array}$ \\
\hline $\begin{array}{l}\text { VIII.14.e2 } \\
\end{array}$ & VIII.15.9 & $B$, p. 78 & & & & & & \\
\hline $\begin{array}{l}\text { IX.1.1 } \\
\end{array}$ & IX.1.1 & & & & & & $\begin{array}{l}\text { p. 603, núm. } \\
143\end{array}$ & \\
\hline IX.1.e1 & IX.1.11 & $\begin{array}{l}C, \quad \text { p. } 105-106 \text {, } \\
\text { núm. I.3.3 }\end{array}$ & & & & & & \\
\hline IX.1.e.2 & IX.1.12 & $\begin{array}{l}\text { C, p. 105, núm. } \\
\text { I.3.3 }\end{array}$ & & & & & & \\
\hline IX.2.e9 & IX.2.15 & & $\begin{array}{l}\text { p. } 419, \\
\text { n ú m . } \\
\text { II.1 }\end{array}$ & & $\begin{array}{l}T, \text { I, p. 288- } \\
289, \text { núm. } \\
101\end{array}$ & & & \\
\hline IX.3.e4 & IX.3.13 & & & & & $\begin{array}{l}\text { p. 233-234, } \\
\text { núm. IV.iv.6 }\end{array}$ & & \\
\hline IX.4.0 & IX.4.1 & & $\begin{array}{l}\text { p. } 534, \\
\text { n ú m . } \\
\text { III.4 }\end{array}$ & & & & & \\
\hline IX.4.3 & IX.4.3 & & $\begin{array}{l}\text { p. } 534- \\
535 \\
\text { n ú m. } \\
\text { III. } 4\end{array}$ & & & & & \\
\hline IX.4.e1 & IX.4.4 & & $\begin{array}{l}\text { p. } 534- \\
535 \\
\text { n ú m } \\
\text { III.4 }\end{array}$ & & & & & \\
\hline $\begin{array}{l}\text { IX.12.2 } \\
\end{array}$ & $\begin{array}{l}\text { IX.12.2 } \\
\end{array}$ & & $\begin{array}{l}\text { p. } 546- \\
547 \\
\text { n ú m } \\
\text { III.5 } \\
\end{array}$ & 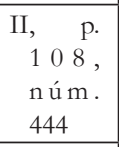 & & & & \\
\hline IX.12.3 & $\begin{array}{l}\text { IX.12.3 } \\
\end{array}$ & & $\begin{array}{l}\text { P. } 547- \\
548, \\
\text { n ú m. } \\
\text { III.5 }\end{array}$ & & & & & \\
\hline IX.12.e3 & IX.12.11 & & & $\begin{array}{l}\text { I, p. } \\
273 \\
\text { nú m. } \\
158\end{array}$ & & & & $\begin{array}{l}\text { Ferrer 1985, } \\
\text { p. } 308\end{array}$ \\
\hline
\end{tabular}

SCRIPTA, Revista internacional de literatura i cultura medieval i moderna, núm. 5 / juny 2015 / pp. 21- 51

ISSN: 2340-4841 · doi:10.7203/SCRIPTA.5.6378 
Helena Rovira Cerdà. Els exempla de Valeri Màxim a la literatura catalana medieval

\begin{tabular}{|l|l|l|l|l|l|l|l|l|}
\hline IX.12.e5 & IX.12.13 & & & $\begin{array}{c}\text { I, p. } \\
368, \\
\text { nú m. } \\
294\end{array}$ & & & & \\
\hline IX.13.e2 & IX.14.1 & C, p. 79, núm. I.2.2 & & & & & & \\
\hline IX.13.e4 & IX.14.3 & & $\begin{array}{c}\text { p. 513, } \\
\text { n ú m . } \\
\text { III.2 }\end{array}$ & & & & & \\
\hline
\end{tabular}

SCRIPTA, Revista internacional de literatura i cultura medieval i moderna, núm. 5 / juny 2015 / pp. 21- 51 ISSN: 2340-4841 $\cdot$ doi:10.7203/SCRIPTA.5.6378 


\section{Resum dels episodis més reproduïts}

I.1.14: Marc Atili Règul després de ser capturat pels cartaginesos és enviat a Roma per negociar el seu intercanvi per altres presoners. Ell mateix parla al senat en contra d'aquest tracte i torna amb els seus botxins per ser cruelment torturat i mort.

II.1.5: Les dones de Roma no beuen vi per tal d'evitar caure en la deshonestedat. A canvi, se'ls permet vestir de porpra, portar ornaments d'or i tenyir-se els cabells.

II.7.1: Publi Corneli Escipió, enviat a dirigir el setge de Numància, dóna com a primera ordre expulsar del campament totes les dones i els mercaders. Així els soldats, ben centrats, derroten en breu la ciutat.

II.7.6: Capítol amb diversos exemples sobre la importància de la disciplina militar. Postumi fa matar el seu fill per haver entrat en combat sense el seu permís. Igualment, Manli Torquat fa occir el seu fill per haver-lo desobeït tot entrant en combat contra Gemini Meci, duc dels toscans.

III.3.e4: Anaxarc és turmentat per ordre del tirà Nicocreont. En comptes de cridar de dolor, retreu al tirà les seves malvestats. Nicocreont amenaça amb tallar-li la llengua i Anaxarc reacciona tallant-se-la ell mateix i mastegant-la amb les dents.

III.7.1: Diversos exemples sobre la confiança en un mateix. El senat reclama explicacions a Publi Corneli Escipió i al seu germà Luci sobre l'administració dels diners públics en la campanya dirigida per ells contra el rei Antíoc. Publi, indignat, recorda al senat els beneficis que li ha aportat la conquesta d'Àfrica duta a terme per ell mateix, de la qual l'únic benefici obtingut pel propi Escipió ha estat el sobrenom «Africà». Escipió captura un espia cartaginès i el passeja per tot el campament per tal que s'adoni de la magnitud del contingent romà.

IV.1.e1: Quan Arquitas de Tarent torna d'un llarg viatge descobreix que, degut a la negligència de l'encarregat de cuidar-li els camps, aquests es troben en molt mal estat. Tanmateix, no actua immediatament contra el culpable per tal que la ira no enterboleixi el seu judici i el castigui massa severament.

IV.1.e2: Plató demana a un amic que castigui a un dels seus servents, ja que la ira li impedeix ser just en la pena. Per altra banda, es nega a creure que el seu deixeble Xenòcrates ha malparlat d'ell. Davant la insistència del calumniador afirma que si realment Xenòcrates ho ha fet, és perquè convenia que així fos.

IV.3.1: Publi Corneli Escipió retorna una captiva hispànica, jove i de gran bellesa, al seu espòs Indíbil sense acceptar cap rescat a canvi. D'aquesta manera es guanya el respecte dels celtibers.

IV.3.5: Mani Curi esdevé un exemple de temprança i moderació en rebutjar una gran suma de diners provinent d'una delegació de samnites, que retornen a la seva terra meravellats en haverlo trobat menjant humilment amb un tallador de fusta.

IV.3.6: Fabrici Luscí es nega a acceptar obsequis dels samnites tot considerant que ser ric no és molt posseir sinó poc desitjar.

SCRIPTA, Revista internacional de literatura i cultura medieval i moderna, núm. 5 / juny 2015 / pp. 21- 51 
IV.5.e1: El jove Espurinna es nafra la cara per tal de fer desaparèixer les sospites dels homes i dels pares de la regió d'Etrúria, que temen que la seva bellesa corrompi les seves filles i esposes.

IV.6.4: Júlia, filla de Juli Cèsar, mor de dolor juntament amb el seu fill nonat en creure erròniament que el seu espòs, Pompeu Magne, ha estat assassinat.

IV.6.5: Pòrcia, filla de Cató, se suïcida menjant-se unes brases en saber que el seu espòs, Brutus, ha mort a Filipos.

IV.6.e2: Hipsicratea es talla el cabell i es vesteix d'home per poder seguir al seu espòs, el rei Mitridates, pertot arreu, també durant l'exili sobrevingut a causa de la derrota davant Pompeu Magne.

IV.7.e1: Damó i Fínties demostren la seva amistat indestructible quan un dels dos s'ofereix com a garant del retorn de l'altre, sentenciat a mort pel tirà Dionís de Siracusa. Quan el condemnat ha posat en ordre els seus assumptes, retorna per sotmetre's al botxí, alliberant el seu amic, que no havia dubtat ni un moment del seu retorn.

IV.8.e2: Gíl lias d'Agrigent no dubta a emprar tots els seus diners en cobrir les necessitats que veu al seu voltant, ja sigui pagant jocs per distreure al poble, donant menjar a la gent, pagant la dot a les joves pobres i rebent hostes, fins i tot en una ocasió que arribaren inesperadament cinc-cents cavalcadors.

V.1.8: Luci Paulus tracta el captiu rei Persa amb tots els honors que la seva dignitat requereix.

V.1.9: Gneu Pompeu conforta al vençut rei Tigranes i li dispensa els honors d'un monarca.

V.1.10: El rei Ptolemeu mata Pompeu Magne a traïció i envia el seu cap a Juli Cèsar. Aquest, tot i l'enemistat passada amb el difunt, plora per la sort de Pompeu i omple el cap d'espècies i perfums per cremar-lo solemnement. Per altra banda, quan li comuniquen la mort del seu enemic Cató, Cèsar afirma que s'havien envejat mútuament i que li conservarà el patrimoni íntegre per als seus fills.

V.1.e1: Alexandre Magne cedeix a un vell soldat el seu seient al costat del foc. En una altra ocasió, estant greument malalt al llit, s'alça a donar la mà a tots els homes que s'hi volen acostar.

V.3.e2: Licurg és violentament exiliat de Lacedemònia, tot i els abundants béns que les seves lleis han portat a la ciutat.

V.4.7: Una filla dóna el pit a la seva mare, que es troba a la presó, per mantenir-la en vida. Quan les autoritats descobreixen la generositat de la filla anul len la condemna de la mare.

V.6.2: El jove Curci, vestit de soldat, es llença a l'interior d'una gran fossa apareguda de sobte al mig del fòrum. El jove actua en resposta a un oracle que afirma que la fossa es tancarà quan estigui omplerta d'allò en què el bé públic és més excel lent.

V.6.e1: La ciutat d'Atenes està essent destruïda pels enemics. El rei Codre pregunta a l'oracle d'Apol lo com evitar-ho i aquest li respon que la guerra acabarà quan el rei mori en mans dels enemics. Pel bé públic, el rei es disfressa de soldat ras i és ferit mortalment durant el combat. 
V.10.e2: El sacerdot Xenofont és informat durant un sacrifici que el seu fill ha estat mort. En saber que ha finat valerosament en combat continua amb el sacrifici afirmant que sent major alegria que pena en conèixer el destí del fill.

V.10.e3: A qui l'informa que el seu fill ha mort, el filòsof Anaxàgoras li respon que bé sabia ell que el seu fill era mortal.

VI.1.1: Lucrècia se suïcida després d'ésser violada per Tarquini, fill del rei.

VI.1.2: Virgini mata la seva pròpia filla davant de la gent abans de permetre que sigui corrompuda pel poderós Api Claudi.

VI.2.e2: Una vella demana als déus que donin al tirà Dionís de Siracusa salut per molts anys. Meravellat per aquesta insòlita demanda, el tirà li pregunta el motiu. I ella respon que cada vegada que han resat per la mort d'un tirà, n'ha arribat un de pitjor. Per això, prefereix quedar-se amb l'actual.

VI.3.e3: Cambises fa degollar a un mal jutge i després estén la seva pell sobre la cadira en la qual s'ha d'asseure el fill.

VI.4.2: Escipió Emilià es nega a enviar a Hispània dos cònsols que ho estan desitjant, l'un perquè és massa pobre i s'aprofitaria del càrrec, l'altre perquè és tan avar que en voldria treure profit.

VI.4.4: Rutili es nega a ajudar un amic a cometre un acte immoral. L'amic li pregunta de què li serveix la seva amistat si no l'ajuda quan ho necessita. Rutili respon preguntant-li de què li serveix a ell la seva amistat si l'impel leix a actuar deshonestament.

VI.5.1: Mentre Camil té assetjada la ciutat de Falèria, un mestre d'aquesta li entrega a traïció uns infants. Camil castiga el mestre i retorna els infants als seus pares, obtenint la rendició de la ciutat com a premi a la seva generositat.

VI.5.e3: Seleuc havia establert per llei que tot adúlter fos cegat. Quan el seu fill és acusat d'aquest delicte, per tal de complir la sentència però no deixar el fill totalment cec, fa treure un ull al fill i l'altre se'l treu a si mateix.

VI.7.1: Tèrcia Emília, esposa d'Escipió Africà, no aireja l'embolic del seu espòs amb una captiva i, quan ell mor, afranqueix la noia i la dóna en matrimoni a un llibert.

VII.3.e5: Una serventa és encarregada de custodiar un dipòsit de dos homes, sota l'encàrrec de no lliurar-la a un sense l'altre. Al cap d'un temps, un dels dos homes torna, afirma que el seu company ha mort i obté el dipòsit. Després arriba el company i, en no trobar els diners, porta la dona als tribunals. Aquesta és deslliurada de tota pena gràcies a l'astúcia del seu advocat, Demòstenes, que afirma que la serventa no pot entregar els diners, si no es presenten els dos homes junts. 


\section{Bibliografia crítica}

Albert, R. / Gassiot, J. (eds.) (1928) Parlaments a les corts catalanes, Barcelona, Barcino.

Arnau de Lieja (2004) Recull d'exemples i miracles ordenatper alfabet, Ysern Lagarda, J. A. (ed.), Barcelona, Barcino, 2 vols.

Autora (2014) El Valeri Màxim d'Antoni Canals: estudi i edició (llibres I-V). Tesi doctoral dirigida per la Dra. Gemma Avenoza Vera, Barcelona, Universitat de Barcelona. Departament de Filologia Romànica, URL: <http://hdl.handle.net/10803/283115>.

_. (2015) "El Valeri Máxim en català: notes sobre la seva difusió al marge d'Antoni Canals", dins Actes del XVI Col roqui Internacional de Llengua i Literatura Catalanes (Salamanca, 1-6 juliol de 2012), en premsa.

AVB (2004) = Paulmier-Foucart, M. / Duchenne, M. C. Atelier Vincent de Beauvais. Centre de médiévistique Jean Schneider (ERL 7229), Nancy, ATILF/CNRS/Université de Lorraine, URL: $<$ http://atilf.atilf.fr/bichard/>.

Badia, L. / Torró, J. (eds.) (2011) Curial e Güelfa, Barcelona, Quaderns Crema.

Baselga y Ramírez, M. (1896) El Cancionero catalán de la Universidad de Zaragoza, Saragossa, Cecilio Gasca.

Bataller, A. (2009) Les traduccions catalanes del "Liber de moribus hominum et de officiis nobilum super ludo scachorum" de Jacobus de Cessulis. Tesi doctoral dirigida pel Dr. Albert Hauf i Valls, València, 2001, Universitat de València. Departament de Filologia Catalana, URL: <http://www.tesisenred. net/handle/10803/9811>.

Biteca (2014) = Beltrán, V. / Avenoza, G. / Soriano, L. (dirs.) "Bibliografia de textos antics catalans, valencians i balears", dins Philobiblon, Berkeley, The Bancroft Library/University of California Berkeley, URL: <http://sunsite.berkeley.edu/PhiloBiblon>.

Bofarull i Mascaró, P. de (ed.) (1857) Colección de documentos inéditos del Archivo general de la Corona de Aragón. Volumen XIII. Documentos literarios en antigua lengua catalana (siglos XIV y XV), Barcelona, Imprenta del Archivo.

Canals, A. (1914) Llibre anomenat Valeri Maximo. Dels dits y fets memorables. Traducció catalana del xiven segle per Frare Antoni Canals, Miquel i Planas, R. (ed.), Barcelona, L’Avenç, 2 vols.

Compagna Perrone Capano, A. M. (1995) "La nau de Lleonard de Sors entre corrents medievals i humanístics", Estudis de llengua i literatura catalanes, XXX. Miscel lània Germà Colón, 3, Barcelona, Publicacions de l'Abadia de Montserrat, pp. 47-67.

Cuartero, M. P. / Mateu, F. J. (1999) "Presencia de exempla afortunados en el De ludo scachorum de Jacobo de Cessolis", Aragón en la Edad Media, 14-15/1, pp. 357-374.

Girona y Llagostera, D. (1919) "Les armes de Catalunya y de Sicilia", Catalana. Revista setmanal, 58, pp. $465-469$. 
Jaume de Cèssulis (1990) El libro de ajedrez de Jacobo de Cessolis: Codex Palatinus latinus 961, Madrid, Encuentro.

Joan de Gal les (1930) Breviloqui, Norbert d'Ordal (ed.), Barcelona, Barcino.

Malla, F. de (1921) Parlaments al Consistori de la Gaia Ciència, Olivar, M. (ed.), Barcelona, Imp. de la Casa de Caritat.

(1981-1986) Memorial del pecador remut. Manuscrit de Barcelona, Balasch, M. (ed.), Barcelona, Barcino, 3 vols.

Martí de Barcelona (ed.) (1929) Doctrina compendiosa, Barcelona, Barcino.

Martín Pascual, L. (2012) "Literatura sapiencial en català i castellà: el cas de la Doctrina d'en Pacs", dins Alemany Ferrer, R. / Chico Rico, F. (eds.) Literatures ibèriques medievals comparades / Literaturas ibéricas medievales comparadas, Alacant, Universitat d'Alacant/SELGYC.

Mehl, J. M. (1978) “L'exemplum chez Jacques de Cessoles", Le Moyen Age: Revue d'bistoire et de philologie, 84, pp. 227-246.

Pujol, J. (1994) "Els 'trobadors estudiosos' segons Felip de Malla”, dins Romero, C. / Arqués, R. (eds.) La cultura catalana tra l'Umanesimo e il Barocco. Atti del V Convegno dell'Associazione Italiana di Studi Catalani (Venezia, 24-27 marzo 1992), Pàdua, Programma, pp. 191-208.

Ramon i Ferrer, L. (1997) Edició crítica i estudi de la "Summa de col lacions" de Joan de Gal tes. Tesi doctoral dirigida pel Dr. Albert G. Hauf i Valls i la Dra. Josepa Ma Cortés i Escrivà, València, Universitat de València. [Tesi en microfitxes amb dues numeracions, una per a l'estudi introductori i una altra per a l'edició]

Redondo, J. (2011) "Sobre la recepción de Plutarco en el primer cuarto del siglo XV: el Memorial del pecador remut de Felip de Malla”, dins Candau Morón, J. M. / González Ponce, F. J. / Chávez Reino, A. L. (dirs.) Plutarco transmisor. Actas del X Simposio Internacional de la Sociedad Española de Plutarquistas (Sevilla, 12-14 de noviembre de 2009), Sevilla, Secretariado de Publicaciones de la Universidad de Sevilla, pp. 633-643.

Rico, F. (1983) "Petrarca y el humanismo catalán", dins Actes del sisè Col loqui Internacional de llengua $i$ literatura catalanes (Roma, 28 setembre - 2 octubre 1982), Barcelona, Publicacions de l'Abadia de Montserrat, pp. 257-291.

Riera i Sans, J. (1984) "Fra Francesc Eiximenis no és l'autor de la Doctrina compendiosa", dins Miscel lània Sanchis Guarner, València, Universitat de València, pp. 289-292.

Riquer, M. de (1993 [1964]) Història de la literatura catalana, Barcelona, Ariel, 4 vols.

Rubió i Balaguer, J. (1936) "La versió llatina de la Crònica general de Catalunya i Aragó", Estudis Universitaris Catalans, 21 [Homenatge a Antoni Rubió i Lluch. Miscel lània d'estudis literaris, històrics i lingüístics, I], pp. 343-355.

Rubió i Lluch, J. (1908-1921) Documents per a la història de la cultura catalana mig-eval, Barcelona, Institut d'Estudis Catalans, 2 vols.

SCRIPTA, Revista internacional de literatura i cultura medieval i moderna, núm. 5 / juny 2015 / pp. 21 - 51 
Helena Rovira Cerdà. Els exempla de Valeri Màxim a la literatura catalana medieval

Santcliment, F. de (1975) Flors de virtut, Cornagliotti, A. (ed.), Barcelona, Barcino.

Soler, R. (2006) Doctrina compendiosa, Wittlin, C. (ed.), Paiporta, Denes.

TCM (2012) = Cabré, L. / Ferrer, M. (eds.) Cens de Traduccions al Català Medieval fins a 1500 (9 de juny de 2012). URL: <http://www.narpan.net/translat-db>.

Valerius Maximus (1854) Valerii Maximi factorum et dictorum memorabilium libri nouem cum Iulii Paradis et Ianuarii Nepotani epitomis, Kempf, C. (ed.), Stuttgart, Teubner. 